\title{
NOTICIAS HISTÓRICAS SOBRE LOS INICIOS DE LA PINTURA REALISTA EN MAGALLANES (1834-1940)
}

MATEO MARTINIC B.

\section{RESUMEN}

Se entrega información acerca del origen y formas de la pintura realista en Magallanes durante la centuria corrida entre los años de 1830 y de 1940, a través del paso ocasional de artistas por el territorio o de su radicación definitiva en el mismo. Se valorizan los correspondientes trabajos y se determinan estilísticamente, todo ello como una contribución para futuros estudios más acabados a cargo de especialistas en historia del arte.

PALABRAS CLAVES: Arte pictórico, Magallanes, Patagonia, pintores realistas.

\section{HISTORICAL EVIDENCE FOR THE ORIGINS OF REALIST PAINTING IN MAGALLANES (1834-1940)}

\begin{abstract}
The paper presents historical information on the origins and modalities of realist painting in Magallanes between 1830-1940, through a review of the production of artists that briefly visited or settled permanently in the region. These works are valorised and classified stylistically as a contribution for more detailed studies by art historians in the future.
\end{abstract}

KEY WORDS: Pictorial art, Magallanes, Patagonia, realist painting. 


\section{INTRODUCCIÓN}

Mucho se ha escrito acerca de la fascinación que la región austral americana -la Magallania-, como todo el continente que integra produjeron en los europeos tras el hallazgo colombino y por los siguientes tres siglos a lo menos. La desmesura y la diversidad de las geoformas del territorio, sus recursos naturales tan diferentes y abundantes, las variedades y características de sus climas y tiempos, y por, fin, la presencia del hombre aborigen con sus distintas culturas llamaron la atención de los visitantes, produjeron fortísimas impresiones en sus ánimos, despertaron o estimularon sus imaginaciones y acabaron originando mitos y leyendas que desafiarían el paso del tiempo.

$\mathrm{Si}$ de tales sucesivas impresiones y sentimientos la literatura se encargó de recogerlos y perpetuarlos en una fecunda producción para el conocimiento, disfrute y asombro de las gentes de Europa, tal proceso se desarrolló necesariamente con la colaboración complementaria de otra expresión de la creatividad humana como es la del arte de la reproducción pictórica, para el caso entendido como una imagen tan realista como se podía de lo que con indudable sorpresa y hasta con fascinación contemplaban los ojos de los viajeros.

Pero en sus diferentes manifestaciones estas representaciones no pudieron liberarse del efecto condicionante de la fuerza imaginativa de los artistas que, bien interviniendo como testigos directos de lo que se describía, bien como intérpretes distantes y posteriores de las observaciones de los cronistas relatantes, acabaron por imponer un estilo singular y propio, que dominaría absolutamente el arte de la representación durante los siglos XVI, XVII y la primera mitad del XVIII, aunque mostrando una progresiva moderación en la fantasía inspirativa hacia formas más veristas, para dar cuenta de las imágenes recogidas.

La representación pictórica así entendida pasó entonces por sucesivas etapas, desde la imagen fantástica del primer tiempo, que pudo alcanzar hasta fines del siglo XVII, pasando por la exótica, generada a partir de entonces durante la centuria siguiente, hasta concluir con la imagen científica, según lo definiera acertadamente Miguel A. Rojas Mix (1970). De esa manera se generó un acervo riquísimo de libros de viajes, atlas y cartas geográficas, en los que se contiene un verdadero tesoro iconográfico. Expresiones caracterizadoras del primer momento son los gigantes y hombres coludos, las sirenas y los monstruos marinos, los pingüinos y avestruces desmesurados en tamaño y otros animales fabulosos, en fin, en tanto que el tiempo del exotismo puede ser ejemplarizado con los exornos de los mapas donde se mostraban palmeras y frutos tropicales, ajenos al frígido y austero ambiente natural del meridión.

Pero, en el transcurso de este modelo o esquema representativo hemos podido encontrar la primera manifestación de realismo, desprovista por tanto de las exageraciones fantásticas comunes otrora. Tal el caso de las figuras humanas y de animales contenidas en el mapa manuscrito y coloreado The Land of Patagona etc. The Draught of Magellan Straits, obra debida al capitán inglés John Narborough, suerte de adelantado en el reconocimiento científico del Estrecho (1670); y particularmente en las acuarelas del ingeniero Duplessis, integrante de la expedición francesa al estrecho de Magallanes comandada por Jacques Beauchesne-Gouin (1699), quien captó con sorprendente realismo escenas de la vida de los indígenas kawéskar del sector central del gran canal y con los cuales los franceses tuvieron una breve relación. Pero, en todo caso, serían éstas (y quizá alguna otra desconocida) las excepciones que confirmarían la regla acerca de la vigencia de un modelo representativo del mundo humano y natural del sur de América, expresado a cabalidad en los grabados de la época.

Avanzado el siglo XVIII, la tendencia insinuaba un inequívoco avance hacia el verismo representativo, e inclusive aquellas imágenes que aún rendían tributo a la fantasía, v.gr. la representación de los patagones agigantados, lo hacen con una mayor naturalidad, si cabe el término (grabados de aborígenes en las obras referidas a los viajes de John Byron y Louis A. de Bougainville). Las expresiones más ajustadas de esta evolución son las ilustraciones del artista inglés Williams Hodges que acompañó al capitán James Cook en su segundo viaje al Pacífico, durante el cual este gran navegante exploró las costas occidental y austral de la Tierra del Fuego (1774). Pues bien, al mismo se deben excelentes grabados, basados en sus dibujos realizados durante el viaje y referidos a paisajes, tal vez los primeros tomados del natural, y a los indígenas yámana, unos y otros de sorprendente calidad. Otro tanto debe decirse de la magnífica obra 
pictórica de los artistas que acompañaron al capitán Alejandro Malaspina en su célebre periplo por la zona meridional de América y en sectores del Pacífico sur entre 1789 y 1794. La inclusión de estos especialistas -José del Pozo y Fernando Brambila principalmente-, característica propia de los viajes científicos, fue todo un acierto, primero por la calidad de las imágenes obtenidas, esto es por el buen dibujo, la calidad de la representación y su apropiado coloreado. No obstante este mérito, tanta rica producción como la que generaron esos artistas durante un lustro, es irrelevante para la historia de la pintura realista en Magallanes por cuanto el paso de la expedición en el viaje inicial del Atlántico al Pacífico, como en el retorno, el trayecto de las naves se hizo por la periferia continental, sin recalada alguna en el territorio, y únicamente se la menciona como un referente acerca de la importancia que tal arte representaba en el conjunto de una tarea científica amplia y tan completa como se quería que fuera, y que al registrarse más tarde con ocurrencia efectiva en el territorio magallánico señalaría el comienzo de la pintura realista en el mismo.

Al enterarse el primer tercio del siglo XIX principiaría la etapa final de un período surgido casi tres medio siglos antes con el hallazgo del Nuevo Mundo, definido por la representación pictórica en una evolución representativa desde el imaginario fantástico a la realidad, en la modalidad expresiva del dibujo y del mismo al grabado, para dar paso a la corta y sin perjuicio de una vigencia temporalmente compartida por unas cuatro décadas, a la generación de la imagen de la realidad física y humana mediante el ejercicio de la pintura en forma.

\section{PINTORES VIAJEROS}

La casualidad brindó al pintor Conrad Martens (1801-1878) la oportunidad de incorporarse a la segunda campaña hidrográfica británica a la Región Magallánica, al mando del capitán Robert Fitz Roy, en calidad de supernumerario del bergantín Beagle, para reemplazar al pintor Augustus Earle que debió abandonar la nave en Montevideo por razón de enfermedad.

En efecto, hallándose Martens de paso en Río de Janeiro con el propósito de proseguir hacia la India, supo de aquella vacante y se dirigió a la capital uruguaya para ofrecer sus servicios, siendo aceptado por el jefe expedicionario (octubre, 1833).
Para entonces Martens, nacido en Londres en 1801, era un pintor con formación académica que se había especializado en paisajes con el afamado acuarelista Copley Fielding. En su historial artístico registraba inclusive una exposición durante ese mismo año 1833 en la Royal Society of British Artists.

La expedición zarpó de Montevideo el 6 de diciembre de 1833 con destino a la costa oriental de la Patagonia y durante el primer semestre de 1834 recorrió diversos sectores de trabajo en la Tierra del Fuego, islas Malvinas y costa de Santa Cruz, ingresando al estrecho de Magallanes para una estadía inicial de pocos días en la zona oriental y una segunda por el interior, que no superó las dos semanas, entre los meses de mayo y junio. Sin embargo de lo breve de esta permanencia, como de la previa en el archipiélago austral de la Tierra del Fuego, entre febrero y marzo, la capacidad perceptiva y el talento artístico del pintor, y su laboriosidad le permitieron realizar una cantidad de bocetos que más tarde se convertirían en pinturas en acuarela y óleo, algunas ciertamente notables por su calidad y su realismo, en una tarea que aunque corta (abandonaría la expedición en Valparaíso durante el segundo semestre de 1834) ${ }^{1}$, contribuiría de manera ponderable a valorizar los resultados científicos de la misma como lo reconocerían más tarde Fitz Roy y Charles Darwin, el más célebre de los supernumerarios que participaron en ella.

En cuanto al número de trabajos conocidos realizados por Martens en la Región Magallánica (Estrecho de Magallanes, Tierra del Fuego), éstos alcanzan a 90, de los que 33 son acuarelas y el resto dibujos a lápiz y tinta, según el catálogo elaborado por R. D. Keynes. Sus motivos fueron los indígenas yámana y aónikenk, panoramas, vistas, paisajes y especímenes de la flora ${ }^{2}$ y la fauna. Pero sin duda alguna sus trabajos más calificados fueron los paisajes que consiguió captar de manera magistral desde Puerto del Hambre (Famine) y sus alrededores. De entre sus trabajos más notables cabe destacar los titulados Mount Sarmiento and the Lomas Range, Port Famine and Mount Tarn, Mount Tarn from the opposite side of Port Famine, Mount Sarmiento

1 Una razón económica obligó a Fitz Roy a reducir en Valparaíso al personal que integraba la expedición.

2 A modo de prueba basta ver la lámina que representa la flor Zapatito de la Virgen (Calceolaria uniflora), incluida por R. D. Keynes en su libro The Beagle Record (Cambridge University Press, 1979) pág. 184. 
from warp Bay and Mount Sarmiento, estos dos tal vez los más logrados de sus paisajes por su fuerza expresiva y su fidelidad naturalista. En ellos, como en toda su obra conocida encontramos suficiente fundamento como para atribuir a Conrad Martens la honrosa posición de fundador o padre de la pintura realista en Magallanes.

Algunos años después de ese paso ciertamente memorable, en diciembre de 1837 arribaba al estrecho de Magallanes la escuadrilla francesa integrada por las corbetas L'Astrolabe y La Zelée, bajo el mando de Jules César Dumont D'Urville, uno de los oficiales más prestigiosos de la armada real gala, camino de los mares y costas antárticos. En lo que interesa, la estadía de las naves fue tan corta como la precedente del Beagle, lo que no obstó, otra vez, para que los pintores embarcados Ernest Goupil (1814-1840) y Louis Le Breton (1818-1866), éste curiosamente embarcado en calidad de cirujano de tercera clase, desarrollaran una serie de excelentes dibujos (y pinturas quizá) con representación de escenas con los aborígenes del Estrecho, especialmente en Puerto Peckett, y paisajes de la sección central del gran canal, unas y otras de admirable fidelidad reproductiva, que sirvieron de base a posteriores litograbados, algunos de los cuales se cuentan entre las representaciones clásicas de la naturaleza de la sección central del estrecho de Magallanes y de sus habitantes indígenas, entre ellos el bien conocido Port Famine, dibujado por Goupil y litografiado por Emile Lasalle ${ }^{3}$.

3 Todas las ilustraciones realizadas durante el transcurso del viaje fueron incluidas en la relación de la expedición Voyage au Pole Sud et dans L'Océanie, bajo la autoría de Dumont D'Urville, para el caso en el tomo primero del Atlas Pittoresque, que la complementa (Gide et. Cie. Editeurs, Paris, 1846). El conjunto realizado en Magallanes incluye once escenas y paisajes, y tres retratos de indígenas aónikenk. Las primeras son las siguientes, con indicación del nombre del pintor, en primer término, y del grabador en segundo: Vue des environs de Port Famine (Goupil, Emile Lasalle); Observatoire de Port Famine (Le Breton, Sabatier); Port Famine (Goupil, Lasalle); Emplacement de l'ancienne colonie de Philipeville (Le Breton, Bichebois); Entrée des forest de la rivière Sedger (Le Breton, Bichebois); fond Du Port Galant (Le Breton, Sabatier); Mouillagge des corvettes sur la baie Saint Nicolas (Le Breton, Bichebois); Fond de la rivière de Gennes (Le Breton, Bichebois); Rivage du Port San Nicolas (Goupil, Lasalle); Campement de Patagons au Havre Peckett (Le Breton, Bayot) y Groupe de Patagons (Havre Peckett) (Le Breton, Bayot).
No obstante que muy poco aportaría a la pintura realista magallánica, cabe mencionar entre los artistas viajeros de ese tiempo al maestro alemán Johan Moritz Rugendas, que como el de muchos otros en la época se hizo por la vía del cabo de Hornos, esto es, por la periferia territorial, hacia 1846. Tal circunstancia le brindó al pintor germano escasas posibilidades de recalada, sin embargo de lo cual, aprovechando algunas, consiguió hacer algunos bocetos sobre indígenas patagones y fueguinos, trabajos a los que hemos hecho referencia en publicaciones anteriores ${ }^{4}$.

En 1848, probablemente hacia mediados de año o a fines del invierno austral, recaló en la rada de Fuerte Bulnes un vapor procedente del Atlántico. En él viajaba como pasajero Alejandro Cicarelli (1811-1879), pintor italiano que había sido contratado por el gobierno del Presidente Bulnes para organizar y dirigir una academia de pintura. Durante su estadía, el artista pintó la que sería su primera obra en Chile, una panorámica desde la punta Santa Ana mirando hacia el sur. El cuadro, al óleo, en tres planos expresivos, muestra al fondo un horizonte de mar y montañas, incluido el monte Sarmiento, que recuerda las pinturas de Martens; en segundo plano, una vista del fuerte, que sería la única que conservaría para la posteridad la imagen de lo que fuera el establecimiento chileno original en la Patagonia, y en un primero, un grupo sobre un suelo nevado en que se observan una persona de civil (probablemente el gobernador José de los Santos Mardones), un religioso franciscano (el capellán Domingo Pasolini) y dos indígenas aónikenk.

Es posible que, como en tantos otros casos, el pintor hiciera durante su permanencia un boceto coloreado, que luego trasladó a una tela, utilizando óleo. Las medidas del cuadro son 1,14 x 0,84 m. Esta pieza, de especial interés histórico, pues es la única representación que se conoce del primer establecimiento de Chile en la Patagonia, se conservó durante muchos años en el Museo Histórico Nacional, Santiago, pero hace algunos años fue transferida al Museo Regional de Magallanes, donde actualmente se encuentra en exhibición.

4 Véase nuestro artículo "Algunos dibujos inéditos de Rugendas sobre indígenas patagones y fueguinos" (Anales del Instituto de la Patagonia, volumen VII, Punta Arenas, 1976). Los originales de los dibujos y bocetos se conservan en la Staatlichen Graphische Sammlung de Munich, Alemania. 
De ese mismo tiempo se conocen otras pinturas (acuarelas), que son obras de autores desconocidos realizadas durante el curso de travesías bien por el estrecho de Magallanes o por el paso del Cabo de Hornos, como son las dos que muestran, respectivamente, a un vapor navegando con fondo de las montañas de la isla Desolación, estilísticamente próxima a la pintura naïf, y un velero cruzando frente al cabo terminal de América. Ambas se incluyen en el conjunto del libro Primera Visión de Chile. Dibujos de la Colección Germán Vergara Donoso, publicado en 1988 por el Museo Histórico Nacional.

Otra mención por lo que pudo haber aportado a la pintura magallánica, de no haber mediado su infausto destino, fue la del pintor alemán Karl Alexander Simon (1805-1852). Con una actividad previa en las zonas de Valdivia, Llanquihue y Chiloé, tal circunstancia lo hizo ser conocido y apreciado por Bernardo E. Philippi, quien lo invitó a viajar consigo a Magallanes cuando el naturalista germano fue nombrado gobernador de la colonia homónima. Tenemos así la certidumbre de que Simon habría llegado a este territorio con el objeto preciso de pintar y dibujar escenas, personas y paisajes para él absolutamente desconocidos y, sin duda por demás interesantes. La fatalidad hizo que cuando en octubre de 1852 se dirigía al campamento principal de los aónikenk en San Gregorio para dar comienzo a su propósito, fuera asesinado por los aborígenes, quizá los mismos guaicurúes que poco después acabarían con la vida del propio Philippi ${ }^{5}$.

El siguiente registro cronológico corresponde a la visita fugaz del pintor norteamericano George Catlin (1796-1872), afamado para entonces como especialista en retratos y escenas de los indígenas de Norte América. Durante su paso por el estrecho de Magallanes en 1856, mientras viajaba de una a otra costa de los Estados Unidos, la nave que lo conducía recaló brevemente en Puerto Peckett y allí Catlin bajó a tierra para hacer algunos bocetos de un grupo de indígenas patagones que solía encontrarse ocasionalmente en el paraje. Desconocemos el número de retratos y escenas que pudo

5 Una apropiada impresión de la maestría de Simon en el arte del dibujo y la pintura puede obtenerse a la vista de la reproducción de algunos de sus trabajos, que hacemos en nuestro libro Los alemanes en la Patagonia chilena. (Hans Storandt, editor, Santiago, 2005). pintar durante el transcurso del viaje fretano, que debieron ser varios, de los que únicamente se han publicado dos ${ }^{6}$.

De ese modo, el lapso 1870-1885 corresponde en general al tiempo final de la expresión artística dibujo/grabado y que resultó asaz fecundo en tanto que documentó gráficamente las relaciones de viaje en lo referido a las particularidades de la vida indígena doquiera la misma pudo ser observada y registrada. El verismo realista monocromo es, sin duda, la característica del trabajo artístico realizado por pintores consumados o dibujantes de circunstancias bien dotados, unos embarcados en las naves que dieron nombre histórico a las correspondientes campañas de trabajo hidrográficas o científicas (Nassau 1866-69; Challenger 1876; Alert 187980 y Sylvia 1882-84, entre las principales); y otros en memorables recorridos terrestres por el interior del territorio patagónico, con protagonistas como el célebre George Ch. Musters (1869-70), James Beerbohm (1877), Florence Dixie (1879), Francisco P. Moreno (1876-77) y Ramón Lista (1878), en fin.

Las obras pictóricas propiamente tales, es decir polícromas, no debieron faltar, pero de ellas se conocen únicamente unas pocas, como es el caso de la bien lograda figuración panorámica del monte Burney, en la península Muñoz Gamero (Patagonia occidental), que da fondo a un paisaje litoral tomado desde la vecindad de las islas Otter, en el canal Smyth?

Situado en una suerte de posición artística transicional, como cerrando un ciclo y reafirmando otro, cabe una mención amplia al pintor alemán Theodor Ohlsen (1855-1913). Con una definida vocación por el arte que devendría su pasión, cultivada con la formación académica obtenida tras sucesivos estudios realizados en el Instituto Artístico de Hamburgo (1873-74), en la Academia de Artes de Munich (1875) y en la Academia de

6 Catlin, George, Episodes from Life Among the Indians and Last Rambles (Norman, University of Oklahoma Press, 1979), págs. 198 y 199; referencias en págs.175-181.

7 Véase el grabado correspondiente publicado originalmente en el libro de Robert O. Cunningham Notes on the Natural History of the Strait of Magellan (Edimburgo, 1871), en que se da cuenta de los trabajos científicos realizados durante las campañas de la corbeta Nassau, que hemos reproducido en nuestro libro Archipiélago Patagónico, la última frontera (Ediciones de la Universidad de Magallanes, Punta Arenas, 2004). 
Pintura de Berlín (1877), Ohlsen arribó a Chile en 1883, instalándose en Valparaíso como retratista, exhibiendo sus primeros trabajos en la Exposición Nacional de 1884. Gran viajero, recorrió diversos lugares del país, en las regiones central, sur y austral, $y$, agudo observador como era, fue captando expresivamente en dibujos a carbón y pluma y en acuarelas las más variadas escenas y personajes correspondientes a distinto orden de actividades, amén de paisajes, lo que hace de él un verdadero cronista gráfico del Chile progresista de la década posterior a la Guerra del Pacífico. Tales vistas las incluyó en un álbum que tituló Dürch Sud-Amerika y que fue impreso en Hamburgo y Leipzig por la casa editora de Louis Bock \& Sohn, en 1894. Se trata de una obra muy poco conocida, joya de bibliófilos, y de notable valor histórico-costumbrista. Pese a tal título, que sugiere un viaje a través o a lo largo del continente, la obra está fundamentalmente referida a Chile, pues de un total de 152 dibujos que incluye el álbum, y que tienen comienzo en el puerto alemán de partida, más de las tres cuartas partes guardan relación con nuestro país y 37 de ellos en particular con la región magallánica. En cuanto a la presencia de Ohlsen en Magallanes, debe suponerse que ella correspondió a dos ocasiones distintas: el viaje de venida a Chile, en 1883, y el de retorno a Europa, probablemente hacia 1892-93. La primera oportunidad es indiscutible, como que la vía del estrecho de Magallanes y la recalada en Punta Arenas eran parte del itinerario de los buques alemanes de la carrera del Pacífico.

En cuanto a la segunda, que supone el retorno al país natal por la misma vía marítima, es una conclusión que basamos en los mismos dibujos del álbum original. En efecto, si bien se incluyen varias vistas que atestiguan el cruce de la cordillera de los Andes por el pintor y su permanencia en Mendoza, todo hace suponer que tal viaje no fue más que una incursión tras la cual Ohlsen regresó a Chile. Abona esta suposición la ausencia de dibujos o croquis relativos a escenas que con seguridad habría contemplado y captado de haber hecho el viaje a través de las pampas entre Mendoza y Buenos Aires. Por otra parte, en el álbum se incluyen muy contadas vistas correspondientes a la capital argentina y al puerto de Montevideo, lo que autoriza a pensar en una permanencia en dichos puntos condicionada por la estadía del vapor en aguas del río de la Plata.
Es muy posible que el pintor viniera recomendado a la casa Wahlen, agente de la Compañía Kosmos, en uno de cuyos vapores navegó, y que una vez en Punta Arenas trabara relaciones con vecinos tales como su ilustrado compatriota Rodolfo Stubenrauch, cónsul del Imperio Germánico, y factor y socio de la firma mercantil Wehrhahn y Cía., o como Enrique Rothenburg, experto capitán mercante, quienes pudieron facilitarle el acceso o traslado a distintos puntos del territorio magallánico. Para la segunda visita, Ohlsen hubo de valerse sin duda de las relaciones establecidas con anterioridad. En la primera estadía, que debió durar probablemente un par de semanas, lapso que mediaba entre las recaladas de itinerario de la compañía naviera, Ohlsen pudo conocer con detenimiento las particularidades de la vida y actividad de Punta Arenas y sus alrededores, incluyendo las cercanas estepas patagónicas y el litoral de la península de Brunswick, obteniendo imágenes y escenas de rico contenido costumbrista y de ponderable valor histórico. Los dibujos relacionados con los indígenas patagones corresponden, en consecuencia, a esta oportunidad, pues por el conocimiento que tenemos de la documentación gubernativa de la época, sabemos de la interrupción de las visitas tradicionales de los mismos a Punta Arenas por varios años, a partir de 1884. Del mismo modo, a esta primera visita corresponderían las vistas tomadas a lo largo de los canales patagónicos, pues fue durante los primeros años de la década del 80, por ejemplo, que la actividad cazadora de lobos marinos se registraba todavía en el área interior de los canales. A la segunda visita, producida alrededor de una década después de la primera, deben atribuirse los dibujos referidos a la Tierra del Fuego, isla Dawson y canales fueguinos, ya que para entonces se hallaba establecida la primera hacienda pastoril en aquel vasto territorio, mientras que la ocupación y actividad misioneras en Dawson, motivos de algunos apuntes, datan de 1889 en adelante. Una observación cuidadosa de las escenas y personajes captados por el pintor da cuenta en algunos casos de una elaboración directa, esto es, con el modelo a la vista, pero en otros, paisajes inclusive, el dibujo sugiere un trabajo posterior en el que el maestro debió poner algo de imaginación. Como quiera que haya sido, se reitera que varias de estas obras corresponden a escenas que jamás habían sido conocidas de no mediar el lápiz y la mirada certera de Theodor Ohlsen. 
Hay en los dibujos -reiteramos-, particularmente en las escenas, vigor y autenticidad tales que no se conocen hasta hoy en otros documentos gráficos contemporáneos, lo que ha permitido conservar, con valor de testimonio objetivo, una época especial de la historia del Magallanes finisecular. Más ostensible es esto en relación con Punta Arenas, centro vital de la zona, cuyos acaeceres y actividades pudo Ohlsen captar cuando ella aún conservaba mucho de su antigua y romántica condición de colonia abandonada, que había luchado duramente por sobrevivir, mientras se podían observar ya los cambios progresistas que imponía la fecundia laboriosa de sus habitantes, animados entonces por un febril impulso de progreso que no tendría fin sino hasta completar, en un par de décadas, el desarrollo colonizador y el asentamiento de la civilización en las tierras del sur americano.

Asimismo, la observación nos permite apreciar que si en la generalidad de los dibujos hay un acabado trabajo profesional, la acucia es mayor todavía en el caso de la representación de paisajes, donde el realismo es evidente, como por ejemplo en el cuadro que tituló Navegando por la Angostura Guía, en que el artista captó magistralmente el espléndido panorama de ese atractivo sector de los canales patagónicos. Así, y no obstante la aparente prescindencia de colorido, que supo reemplazar con un bien logrado empleo de matices de grises y negros, cabe reconocer en Theodor Ohlsen a un cabal pintor realista.

Thomas Somerscales (1842-1927), el gran marinista de la pintura chilena, también pasó como viajero por las aguas de Magallanes y no fue ajeno a las sugerencias que emanan del áspero pero atractivo paisaje que caracteriza a su vasto distrito occidental. Nacido en Kingston-upon-Hull, Inglaterra, en 1842, desde muy joven, por tradición familiar parecía destinado a la vida naval. De hecho, tras graduarse como profesor de Estado a los veinte años, revistó por primera vez en una nave de la armada de $\mathrm{Su}$ Majestad Británica, el Cumberland, carrera que prosiguió sucesivamente embarcado en las naves Clío, Duke of Wellington, Liffey, Chanticleer y Zealous, en una permanencia continua de seis años que le brindó un conocimiento acabado sobre la vida en el mar y sobre la arquitectura naval. Pero la tradición familiar que así parecía influir sobre su joven existencia corría por doble vertiente, esto es, también por la vía artística, con una marcada afición por la pintura, vocación que Somerscales supo cultivar con ahínco y que no dejó de lado mientras ejercía como docente naval, adquiriendo así una rara maestría que inevitablemente hubo de asociar con su natural inclinación por el mar.

La fiebre malaria que contrajo durante un viaje por el trópico cuando pasaba de los veintiséis años, lo obligó a abandonar el servicio en Valparaíso en 1869, puerto que ya había conocido con anterioridad y en el que pasó a radicarse. Ya establecido, su inclinación por la pintura y la maestría que exhibía le llevaron a dedicarse de lleno a la misma. Se relacionó con otros artistas y pintores, y abrió un taller para la ejecución de sus obras y la enseñanza del arte, del que con los años saldrían algunos discípulos notables como pintores de fama, tales como Alfredo Helsby y Álvaro Casanova Zenteno, entre otros. Su prestigio se acrecentó luego que en 1872 participara en la Primera Exposición Nacional de Santiago, como pintor paisajista, ganando una medalla de plata. Inició así una carrera que fue afirmando sólidamente en tanto que sus cuadros eran conocidos y apreciados. La Guerra del Pacífico (1879-1884) fue en cierto modo una coyuntura vital que, unida al evidente cariño que sentía por Chile, le brindó la posibilidad de ser el mejor artista que supo plasmar en las telas las glorias navales de la que ya consideraba era su patria adoptiva.

En 1892, tras más de dos décadas de permanencia en el país, con esposa e hijos chilenos, decidió retornar a Inglaterra, gozando ya de merecida fama como pintor marinista. Desde entonces en adelante trabajó intensamente, cimentando su bien ganado prestigio participando en las muestras veraniegas de la Real Academia. Su producción pictórica se acerca a las 600 piezas, que se hallan dispersas en distintas colecciones británicas y chilenas, tanto públicas como privadas, habiendo gozado desde largo tiempo y hasta el presente de muy alta estima y cotización en el ambiente del arte pictórico.

Parte de esa obra, la referida a Chile, incluye la Región Magallánica. Ello fue posible por sus repetidos viajes a Chile luego de su alejamiento, cinco en total, que tanto en la venida como en el retorno hizo por la vía del estrecho de Magallanes. Ello permitió particularmente a Somerscales familiarizarse -e impresionarse sin duda- con la grandiosidad y la sugerencia inspiradora del paisaje de la sección 
occidental del gran canal, atractivo tanto en sereno como con tormenta, y hacer bocetos que más tarde elaboraría en su taller, logrando así algunas espléndidas marinas. Dando por segura más de alguna omisión, cabe considerar los siguientes trabajos pictóricos referidos a Magallanes: Off Cape Pilar (1902) ${ }^{8}$; In the Straits of Magellan, pintado también en 1902, tal vez la primera interpretación del paso de Francis Drake por el Estrecho en 1578, episodio del que hubo otras dos subsiguientes realizadas en 1914 y con el título común de Francis Drake's pasaje through the Straits of Magellan; una de ellas corresponde al estupendo óleo sobre tela, de gran tamaño $(2,93 \times 1,23 \mathrm{~m})$ y que pertenece a la pinacoteca del Banco de Chile. In the Straits of Le Maire, denominación atribuida al parecer por uno de sus comentaristas (1907) y que se ha interpretado como pintura realizada por el artista teniendo en mente el recuerdo de Drake o más bien el de Lord Anson, navegante que a mediados del siglo XVIII utilizó aquel paso en su ruta hacia el Pacífico, embarcado en el Centurion"; The "General Baquedano" in a Gale (1910) ${ }^{10}$; A Pacific Steam Navigation Co. Vessel in the Straits of Magellan (1910); In Crooked Reach (1911); A Chilean Barque in the Straits of Magellan (1917) y Velero cruzando el Estrecho de Magallanes; piezas repartidas entre diferentes propietarios.

En su mismo estilo marinista corresponde mencionar a otros dos pintores contemporáneos de Thomas Somerscales, el chileno Álvaro Casanova Zenteno (1857-1939) y el alemán Carl Wilhem Schnars-Alquist (1855-1939). El primero, ya mencionado como alumno del gran maestro anglo-chileno, que fue un eminente servidor público en diferentes actividades administrativas, militares y diplomáticas, mostró tempranamente una inclinación por el arte pictórico que le llevó a realizar estudios de dibujo en París, que prosiguió más tarde con clases impartidas por los maestros Pascual Ortega, Onofre Jarpa, Enrique Swinburn y Thomas Somerscales,

8 Las denominaciones de los cuadros más bien parecen sugeridas por terceros que impuestas por el propio artista.

9 Alex A. Hurst, autor de Thomas Somerscales Marine Artist. His life and work (Teredo Books, Brighton, Sussex, 1988), comenta que esta fue una obra conjetural y que no llegó a acabarse completamente.

10 Aquí el escenario es igualmente la boca occidental del Estrecho, con las rocas características del cabo Pilar al fondo. de quien llegó a ser discípulo por la línea estilística asumida en sus pinturas. De su obra, que le ganó fama merecida, sólo conocemos tres excelentes cuadros: dos que representan el paso descubridor de Fernando de Magallanes por el estrecho de su nombre, salida occidental, en 1520 , uno pintado en 1920 (1,20 x 1,80 m), que se exhibe en uno de los salones del Casino de Oficiales de la Guarnición Militar y otro ejecutado en fecha indeterminada (1,20 x 2,00 m), que se muestra en el hall de entrada del Teatro Municipal, ambos de Punta Arenas, y un tercero titulado El abrazo del Estrecho de Magallanes (11,03 x 1,94 m), que rememora el episodio del encuentro de los Presidentes Federico Errázuriz, de Chile, y Julio A. Roca, de Argentina, en Punta Arenas (1899), y que se exhibe en un salón de las oficinas de Santiago de la Comandancia en Jefe de la Armada de Chile, y que debió ser pintado durante la primera década del siglo $\mathrm{XX}^{11}$.

Del pintor alemán Schnars-Alquist son escasas las noticias que poseemos, pero vista la calidad de sus obras es indudable que tuvo formación académica, como es evidente que el mismo hubo de pasar navegando en fecha indeterminada por las aguas del estrecho de Magallanes, circunstancia que le brindó la oportunidad para inspirarse y recoger algunas escenas paisajísticas. Entre sus obras corresponde mencionar El crucero "Esmeralda" de la Armada de Chile saliendo del estrecho de Magallanes en las cercanías del cabo Pilar, que se exhibe en el Casino Naval de Valparaíso, y The Magellan Straits, espléndido óleo que muestra el paisaje occidental en un día de temporal de viento, en el que se ha captado magistralmente las nubes de agua pulverizada originadas por la fuerza eólica sobre la superficie del marr ${ }^{12}$. Esta es una prueba cabal de la gama de posibilidades que ofrece al artista pintor la influencia del clima, del tiempo atmosférico en el caso, sobre el paisaje. Otros cuadros suyos son Salida del Estrecho de Magallanes que por su denominación sugiere que pueda tratarse de alguna de las obras precedentes mencionadas, y Evangelistas, óleo este que integra la pinacoteca del Club Naval de Valparaíso.

11 Una aplicación institucional, Armada de Chile Pinacoteca (Santiago, 1996), da como fecha de ejecución el año 1887, lo que es evidentemente un error pues el suceso que se representa aconteció doce años después.

12 Este cuadro, de 81,3 x 129,6 m, fue subastado por la casa Christie's de Londres el 21 de septiembre de 2005. 
El siguiente registro en la nómina de pintores realistas en Magallanes corresponde al norteamericano Rockwell Kent (1882-1971). Personaje singular y controvertido, se desempeñó en su larga vida como dibujante de arquitectura, ilustrador y pintor, impresor y publicista, carpintero de ribera, pescador de langostas, granjero, explorador y viajero, escritor y activista político con ideas de avanzada social. Con vocación por la pintura, se inició académicamente en la Horace Mann School de Nueva York, que prosiguió con los estudios de arquitectura en la Universidad de Columbia, que abandonó a punto de concluirlos forzado por la inclinación que sentía por el arte pictórico, lo que le condujo a tomar clases de la especialidad en la Shinnecock Hills School, con el maestro William Merritt Chace y posteriormente en la New York School, con los pintores Robert Henri y Kenneth Hayes Miller, que concluyó con un aprendizaje, a modo de práctica, con Abbot Thayer en Dublín, New Hampshire. Con talento nato, una adecuada formación académica, a la que sumó su afición por la naturaleza, acabó por ser un intérprete magistral de la misma a través de una obra fecunda y prolongada que abarcó desde la xilografía y el dibujo impreso hasta la pintura al óleo. En su interacción con el ambiente natural desarrolló una rara habilidad para captar las tonalidades de la luz y el colorido de las formas vitales e inertes, que plasmó en dibujos y pinturas con un estilo peculiar limpio y sencillo, en que prescindiendo de los detalles conservaba los rasgos esenciales de las figuras dominantes en un panorama escénico que supo representar con gran vigor, sin menoscabo de la realidad, lo que debe ser tenido como un verdadero logro. En síntesis, fue un verdadero exponente del realismo pictórico, según los cánones del modernismo en boga hacia los años de 1920 y 1930 o, si se prefiere, del realismo socialista en la expresión artística de acuerdo con las normas del marxismo soviético, de cuyas ideas participó con entusiasmo.

En lo tocante a Magallanes, su espíritu aventurero lo trajo hasta el Estrecho a fines de 1922 desde Nueva York a Punta Arenas, a bordo del vapor Curaca. Una vez aquí adquirió un bote ballenero que hizo acondicionar con aparejos de sloop y que al ser lanzado al mar recibió el nombre de Kathleen, embarcación con la que emprendió un viaje de conocimiento exploratorio que lo condujo por el fiordo del Almirantazgo hasta el corazón de la Tierra del Fuego, el lago Fagnano, para desde allí cruzar los Andes Fueguinos y alcanzar la costa del canal Beagle en una travesía ciertamente esforzada y no exenta de peligros. El viaje lo completó con visitas a Ushuaia y Harberton en la parte argentina de la Tierra del Fuego, y con un interesante periplo navegatorio por las islas del cabo de Hornos hasta el final del continente americano. Frutos del recorrido fueron en lo literario un libro que tituló Voyaging southward from the Straits of Magellan (G. P. Putnam's Sons/The Knickerbocker Press, 1924), que supo ilustrar con magníficas xilografías en blanco y negro, y, en lo artístico, con una serie de óleos que recogieron los diferentes paisajes naturales del territorio conocido.

Su adhesión a las ideas políticas de avanzada le generaron tanto dificultades y situaciones molestas en su patria, como despertaron admiración por su obra en la Unión Soviética, con cuya gente simpatizó al punto de donar al pueblo ruso una gran cantidad de pinturas y grabados (actualmente en poder del Museo de L'Hermitage), lo que le hizo acreedor al Premio Lenin de la Paz en 1967. Pero ello, al fin, no menoscabaría el reconocimiento y la admiración de la posteridad por su obra pictórica, de singular realismo, parte de la cual tuvo feliz inspiración en las aguas, tierras y cielos de Magallanes, y que es virtualmente desconocida hasta hoy para sus habitantes y aun para los chilenos en general.

Los últimos pintores viajeros cuyo paso por la Región hemos registrado fueron el alemán Eduard Schloemann (1888-1941) y el anglo-holandés Stephen Koek-Koek (1887-1934), ambos activos para el caso durante los primeros años de 1930.

La razón de la presencia del primero en Magallanes estuvo en la influencia del aviador Gunther Plüschow, afamado por sus exploraciones y viajes marítimos y aéreos en la Tierra del Fuego y Patagonia chilena entre 1928 y $1931^{13}$, quien pudo entusiasmarlo para venir y pintar la soberbia naturaleza austral y sus paisajes humanizados. Schloemann arribó al territorio hacia fines de 1930 y permaneció aquí por los dos años siguientes.

Nacido en Dusseldorf y con vocación temprana por la pintura, estudió en la Academia de Arte

13 Véase su libro clásico Silberkondor uber Feuerland (Verlag Ullstein, Berlín, 1929) o su traducción al español, Sobre la Tierra del Fuego (Ediciones Simurg, Buenos Aires 2005). 
de su ciudad natal, formación que enriqueció con viajes por Inglaterra, Holanda y Suecia. No muy conocido inicialmente en su patria, al parecer fue más valorado al retorno de Chile y gozó de cierta popularidad y aun de favoritismo durante la vigencia del régimen nacional-socialista como pintor de escenas navales y marítimas. Tal vinculación política tendría más tarde consecuencias para el pintor, pues lo condujo -a su memoria, pues Schloemann falleció al ser torpedeada la nave en que viajaba por el Mediterráneo- a una suerte de ostracismo, al ser ignorado y olvidado después de la Segunda Guerra Mundial. Un hecho fortuito acaecido hace algunos años atrás hizo que Felipe Ernst, a la sazón Segundo Secretario Encargado de los Asuntos Culturales de la Embajada de Chile en Alemania, conociera a una hija ya anciana del pintor y así pudo enterarse de la obra artística realizada por su padre en nuestro país ${ }^{14}$. Este hecho, al valorizarse debidamente la noticia, y visto el interés que podían concitar las pinturas por su carácter inédito, condujo a la organización de una exposición especial con el conjunto de cuadros con temas chilenos -magallánicos-, que se realizó durante el mes de marzo de 1995 y que fue inaugurada por el Presidente Eduardo Frei Ruiz-Tagle durante su visita oficial a Alemania, con el título de Eduard Schloemann Landschaftsmalerei aus Feuerland und Patagonien (Eduard Schloemann, pintor de paisajes en Tierra del Fuego y Patagonia) en el Museo de Bellas Artes de Bonn ${ }^{15}$.

Arribado a Punta Arenas, Schloemann encontró buena acogida entre sus connacionales residentes y otras personas, lo que le permitió viajar y conocer diferentes zonas y lugares del territorio magallánico, en su sector central (península de Brunswick, isla Riesco), en la Tierra del Fuego y en Última Esperanza, particularmente en el atractivo y aun poco conocido distrito montañoso-lacustre señoreado por el macizo del Paine, hoy afamado mundialmente. Los antecedentes con que se cuenta permiten afirmar que Schloemann pintó más de medio centenar de cuadros durante su permanencia en Magallanes. $\mathrm{Su}$ temática fue variada, yendo del paisaje urbano al

14 La señora Tschaschel, su apellido de soltera, poseía sesenta cuadros pintados por su padre.

15 Entonces nos correspondió intervenir con antelación a petición del Agregado Cultural de Chile en Bonn para identificar los lugares a los que correspondían las pinturas. rural, propiamente a las panorámicas de la espléndida naturaleza patagónico-fueguina, que supo captar en forma realista aunque con un inconfundible sello estilístico personal, de gran fuerza expresiva por su vivo colorido.

Se sabe también que durante su permanencia en Punta Arenas, el pintor utilizó como taller de circunstancias un amplio espacio disponible en la Mueblería Bahrfeldt, en donde desarrollaba y daba acabado a sus pinturas que, según se ha conservado por la tradición, boceteaba en terreno con algunos trazos elementales pintados con su dedo índice. Schloemann expuso sus cuadros en Punta Arenas, al promediar 1931, y en Santiago, con el auspicio del Departamento de Turismo (junio 1931), muestra esta que fue bien acogida por la crítica especializada, al punto de escribirse que en algunos casos [las pinturas] alcanzan la genialidad ${ }^{16}$. Una mínima parte de su producción quedaría en Punta Arenas en poder de gente amiga y el grueso lo llevó consigo el pintor a su retorno a Alemania.

Schloemann, como artista pintor, ahora redescubierto, debe ser considerado no sólo un buen ejemplo del realismo pictórico en Magallanes, sino, como tal, el primero que en su género contribuyó a dar categoría universal a las bellezas naturales de la Patagonia chilena -montañas, glaciares, lagos, etc.- cuya esplendidez y sugerencia recogió con un estilo personal y verista ${ }^{17}$.

Stephen Koek-Koek fue todo un personaje singular, además de eximio pintor. Su padre fue el artista holandés Hermann J. Koek-Koek, quien se estableció en Londres en 1869, originando una familia anglo-holandesa vinculada con el arte pictórico, como parte de una tradición de largo tiempo.

16 La Nación, edición del 18 de junio de 1931.

17 Aunque no hay certeza, es posible conjeturar acerca del uso de las pinturas de Schloemann en la propaganda comercial de la casa G. Liebig, muy conocida en la época, dado el parentesco estilístico que notamos en los motivos reproducidos en las etiquetas (paisajes de montañas, glaciares, lagos, bosques, etc.). Si la conjetura no es válida debe aceptarse que hubo por entonces, o antes, otros pintores alemanes visitantes no conocidos, posibilidad que afirmamos a la vista de la tarjeta postal en colores que muestra un vapor de la Compañía Naviera Kosmos en el estrecho de Magallanes, con fondo de montañas nevadas. La tarjeta fue editada por Meisser \& Buch Leipzig, Künstler-Postkarten Serie 1012, y reproducida en nuestra obra mencionada (pág. 84). Aunque se ve la firma del autor en el lado inferior izquierdo, la misma es ilegible. 
No poseemos datos sobre la formación propiamente académica de Stephen, más allá de su talento innato, pero sí se sabe que ya pintaba a los catorce años, iniciando así una carrera signada por una producción asaz fecunda. Emigró muy joven a América del Sur, con una estadía inicial breve en Lima, Perú (1910) y posteriormente pasó a Chile, radicándose en Valparaíso por algún tiempo (1913); luego en 1914 se fue a Argentina, estableciéndose en Mendoza, donde contrajo matrimonio y nació un hijo. En 1916-17 estuvo de nuevo en Chile, pero al año siguiente retornó a Argentina, en lo que sería su permanencia americana más prolongada, radicándose en Buenos Aires, pero también realizó viajes por ciudades del interior e incluso se trasladó temporalmente a Montevideo, Uruguay. Pintor laborioso, casi compulsivo, sus cuadros pudieron contarse por centenares. Trabajaba por encargo y por propia iniciativa, generalmente para procurarse recursos por venta de los mismos, pues el dinero nunca pareció bastarle de modo suficiente. De temática universal, la misma pudo variar entre aspectos religiosos, paisajes, marinas, retratos, en fin. Bien asesorado por Carlos Orero, su agente comercial, a quien conociera en Santiago de Chile, organizó diferentes exposiciones con sus obras en las galerías de mayor prestigio de Buenos Aires, como en otras ciudades argentinas y en Montevideo, con gran éxito de ventas. Pasado 1920, la fama adquirida le mereció recibir un encargo del Gobierno Nacional, pues se deseaba obsequiar a Eduardo de Windsor, Príncipe de Gales, durante su visita al país en 1924, obra se tituló Veleros en Sol de Mayo y respecto de la misma corrieron después historias que daban cuenta de que habiéndola concluido y no habiéndosele adelantado dinero en pago, apremiado como solía estar la vendió a terceros; o que habiendo recibido el encargo dejó pasar el tiempo sin hacer nada y urgido por el comitente pintó el cuadro en una sola noche, doce horas antes de que llegara el regio visitante. En todo caso se pagó por ella la suma de \$12.000 argentinos, toda una fortuna para la época y el medio.

Si pintaba compulsivamente como se ha afirmado y ganaba dinero, el mismo se le hacía agua entre las manos, desordenado como era en su vida privada por causa de su afición al alcohol y a las drogas, circunstancia lamentable que hizo que Koek-Koek viviera crónicamente apremiado, situación que repetida y agravada condujo a su internación en un hospital en procura de su rehabilitación (1926). Mientras se le trataba de su intoxicación pintó sin descanso, con lo que pagó a los médicos que lo atendían y obtuvo recursos para rehacer su existencia. Pero, así y todo no consiguió recuperar el esplendor de otrora y recayó en el vicio que acabó llevándolo progresivamente a la ruina moral, física y económica. De esa manera no pudo cumplir con sus deudas crecientes y acabó por emigrar a Montevideo. Corría 1933 y allí, de algún modo se relacionó con la rica familia Menéndez Behety de Punta Arenas, quizá con Alfonso Menéndez Behety, hombre proclive al arte y la cultura. Obtuvo así un pasaje en barco para dirigirse a la ciudad del estrecho de Magallanes, a la que el pintor llegó cuando el año terminaba.

Una vez aquí, se repitió lo acontecido en otros lugares. Realizó una cantidad de obras, se ignora cuántas, pero al parecer unas tres decenas a lo menos, o quizás más, unas por encargo y otras por su cuenta para satisfacer su incontrolable adicción a la bebida, según lo recogería la tradición local. Otra vez, como era habitual, su temática fue universal y, de manera excepcional, asociada a lo regional. Sus cuadros, todos de gran calidad, quedaron en manos de diferentes propietarios, que aún los guardan como tesoro artístico preciado, pero tal vez las mejores piezas las conservó Alfonso Menéndez Behety, el generoso mecenas que le permitió sobrevivir. Parte o la totalidad de esas piezas fueron a adornar las paredes de su espléndida residencia, algunas de las cuales permanecieron en ella cuando Menéndez, en gesto magnífico, la regaló al recién electo obispo de Punta Arenas, monseñor Vladimiro Boric (1947). Allí continúan hasta el presente. En las oficinas del gobierno regional de Magallanes se conserva un cuadro de gran tamaño $(1,03 \times 1,70 \mathrm{~m})$ que representa el paso de las naves descubridoras de Fernando de Magallanes en 1520. De vivo colorido y gran fuerza expresiva es, para nosotros, el típico cuadro pintado "de memoria", es decir, sin modelo paisajístico ni cultural a la vista. Se ejecutó en 1933 y fue donado a la Intendencia de Magallanes por Carlos Menéndez Behety. 
Estos trabajos, incluida una nueva exposición para todo público abierta en enero de $1934^{18}$, mantuvieron ocupado a Koek-Koek por algunos meses, al cabo de los cuales su espíritu nomádico tornó a manifestarse, marchándose ahora a la capital chilena. Allí, el 24 de diciembre de 1934 se le encontró muerto en el hotel "France" en que se alojaba, al parecer a consecuencia de una intoxicación aguda por la ingestión de alcohol y barbitúricos ${ }^{19}$.

Tal fue el curioso y singular personaje, un pintor eximio que virtualmente concluyó su carrera artística en Punta Arenas, dejando aquí alguna huella de arte realista, en la modalidad que puede calificarse de realismo impresionista.

Corresponde cerrar el ciclo de los pintores viajeros de paso por Magallanes con el maestro chileno Pedro Luna (1896-1956). Con definida vocación, ingresó muy joven a la Escuela de Bellas Artes (1912) donde tuvo por profesores a los pintores afamados Juan Francisco González, Alberto Valenzuela Llanos, Julio Fossa, Pedro Lira y Fernando Álvarez de Sotomayor, entre otros, bajo cuya conducción su talento natural se enriqueció con una formación académica calificada. En 1920 fue enviado a Europa por el gobierno chileno para perfeccionarse en el estudio de la pintura decorativa, permaneciendo allí por dos años, tiempo durante el cual recibió lecciones del maestro español Eduardo Chicharro $y$, en el curso de algunos viajes, pudo conocer a los ya célebres pintores Cézanne y Manet.

Para entonces, Luna era ya un artista fecundo, que mostraba una clara preferencia por la

18 La Revista Menéndez Behety (No. 121, Enero de 1934) dio cuenta del suceso de la siguiente forma: "Exposición Koek-Koek". El 4 del corriente fue inaugurada en el local del edificio de "La Polar" la exposición de cuadros del pintor Stephen Koek-Koek, que nos visita actualmente. Esta exhibición la constituyen un regular número de cuadros, sobre diversos motivos, cuya feliz realización cautiva de inmediato el interés del visitante. Koek-Koek se revela un verdadero maestro en la tendencia original que cultiva, lo cual da a su obra un sello personal e inconfundible. Fuera de ser una de las mejores muestras que se han presenciado aquí desde algunos años a esta parte, los cuadros de KoekKoek son una manifestación de las corrientes de avanzada que cada día ganan más adeptos en el arte de la pintura.

19 Fue sepultado el 28 de diciembre de 1934 en el Cementerio General de Santiago, bajo la modalidad de tumba temporal (cinco años), lo que supone que una vez vencido el plazo y si no fue renovado, los restos fueron depositados en la fosa común. pintura descriptiva de la sociedad de su tiempo. Este interés, una vez que regresó al país, lo llevó a viajar por distintas provincias, incluso con residencias prolongadas en ciudades como Traiguén (1924) y Linares (1930). Su afán por conocer nuevas gentes y geografías lo trajo hasta el entonces remoto Magallanes, al que arribó en 1935 viajando en barco desde Puerto Montt.

Aplicado en su trabajo, aprovechó la travesía para pintar varios cuadros con paisajes, tales como los que tituló Angostura Inglesa, Canal de Magallanes, Nevazón en Puerto Natales, Lanchón de Magallanes y Puerto de Magallanes ${ }^{20}$, todos de gran riqueza cromática que estilísticamente recuerdan a otros pintores contemporáneos ya mencionados, como Schloemann y Koek-Koek. Pero fue su obra titulada Cabaret en Magallanes, mejor conocida como El Baile de las Enanas (1936), la que concitaría la mayor atención de los críticos y especialistas de arte, y que motivaría variadas consideraciones.

Para una mejor comprensión del punto debe tenerse presente que Pedro Luna era un hombre amante de la juerga y la vida disipada y, como tal, afecto a los lugares donde la misma se desarrollaba. Así, durante su permanencia en Punta Arenas frecuentó diferentes prostíbulos, en uno de los cuales fue testigo (¿protagonista?) de la escena que su capacidad de observación y su mano magistral recogerían con verismo descriptivo, aunque algo caricaturesco, y con vigoroso colorido.

El cuadro muestra el salón de un burdel quizá de baja categoría ${ }^{21}$, en el que destacan como figuras centrales dos parejas que bailan, en las que las mujeres son de baja estatura y claramente deformes en sus piernas, característica que se procuraba disimular o disminuir con vestidos largos. El supuesto "enanismo" de esas prostitutas, en vez de corresponder al conocido trastorno del crecimiento por razones genéticas, con sus características tipificadoras (estatura reducida, cortedad y deformidad de miembros, desproporción entre los mismos, etc.), que han aceptado los comentaristas, en realidad tenía otra causa, al parecer desconocida por ellos.

20 Debe tenerse presente que por esos años Punta Arenas había sido rebautizada con el nombre de "Magallanes".

21 Fundamos el aserto en el hecho de que sólo un establecimiento de bajo nivel podría recibir asiladas del tipo de las que más abajo se describen. 
Esas infelices mujeres retratadas, con seguridad jóvenes, manifestaban en su deformidad física el raquitismo que afectó al estrato más pobre de la sociedad magallánica (puntarenense) durante los años de 1910 y parte de los de la década siguiente, debido a la falta de consumo de leche, con resultado lamentable, pues niños nacidos normales, crecieron anormalmente por razón de carencia de calcio, haciéndose notar por sus piernas torcidas hasta lo increíble (popularmente llamados "chuequitos"). La seriedad de ese mal provocó la preocupación pública, alarmó a las autoridades y permitió al fin su erradicación tras una campaña médico-sanitaria sostenida por años, hacia fines de los años de $1920^{22}$.

Los otros personajes incluidos en la escena pintada, aparte del carabinero y del hombre de campo, sendos compañeros de las "enanas", son los componentes de una "orquesta típica" (al estilo de Buenos Aires), común en la diversión social de la Punta Arenas de la época, formada por un bandoneonista, un violinista, un pianista y un baterista; también se observa un marinero borracho durmiendo sobre una mesa; otra pareja, por así decirlo normal, formada por un hombre cuya vestimenta señala su condición social media o superior, y una mujer normal; y por otras tres figuras, dos individuos gigantones, uno de los cuales se entretiene con otra mujer, al parecer también "enana"23.

De esta manera, Pedro Luna, integrante calificado de la "Generación del 13", aportó a la historia de la pintura realista en Magallanes con una obra ciertamente excepcional de descripción social, que permite introducirse en los ambientes del bajo Punta Arenas de los años de 1930.

Los pintores a los que se ha hecho mención extensa o breve, no agotan ciertamente el registro de los artistas que pudieron pasar por Magallanes $e$ inspirarse temáticamente en su naturaleza o en

22 Tal fue la situación, que uno de los primeros documentales cinematográficos producidos en Chile por ese entonces (por Antonio Radonich y José Bohr, pioneros de la actividad) estuvo dedicado a dar cuenta del raquitismo en Magallanes y por su calidad testimonial fue exhibido especialmente ante el Presidente de la República Arturo Alessandri y sus ministros. Sobre el particular véase del autor, Historia de la Región Magallánica, (segunda edición, Ediciones de la Universidad de Magallanes, Punta Arenas, 2006 (1992), tomo III, págs. 1096 y siguientes).

23 La obra pertenece a la colección particular del señor Ricardo Mac Keller. episodios de su historia. Así, conocemos reproducciones de algunos excelentes óleos referidos a sucesos acaecidos en los bravíos mares del cabo de Hornos, por los que entre 1850 y 1930 transcurrió la afamada ruta de los clippers, los grandes veleros que venían desde ultramar hasta el Pacífico y viceversa. Entre esas piezas se encuentran dos espléndidos cuadros que muestran los momentos finales de la barca alemana Pinnas, siniestrada en 1929 tras sufrir el castigo durísimo de una tempestad, que recuerdan cercanamente la maestría pictórica de Thomas Somerscales ${ }^{24}$.

Asimismo hacia fines de los años de 1940 llegaron hasta Punta Arenas algunos pintores de renombre, como Arturo Pacheco Altamirano, Benito Rebolledo Correa y Rudolf Pintye, en plan de exhibición y venta de sus obras, pero no consta, excepción hecha tal vez del último mencionado, que pintaran durante su estadía algunos motivos de inspiración regional. Es posible también que en una época indeterminada anterior hubiera visitado Magallanes el pintor Luis Strozzi, en plan de conocimiento y ejecución de alguna obra, pero de ello no hay certidumbre fehaciente.

\section{PINTORES RESIDENTES}

Arribado hacia 1899 en calidad de "tourista fotógrafo", enviado al parecer por la revista Caras y Caretas de Buenos Aires, de la que era colaborador, Carlos Foresti (1872-1932), originario de Italia, acabaría por radicarse en Punta Arenas hasta su muerte. Hombre instruido y culto ejerció desde un principio como fotógrafo y como publicista al dar a luz a poco de su establecimiento el álbum Punta Arenas-Álbum Recuerdo que contiene cuarenta y cinco fotografías de su autoría que informan sobre lo que era la capital magallánica cuando ya mostraba hechuras de pequeña metrópoli patagónica. Años después, en 1920 y motivado quizá por la conmemoración del cuarto centenario del descubrimiento del estrecho de Magallanes, entregó su Álbum del Territorio de Magallanes, obra de gran formato y calidad, que incluye doscientas sesenta vistas ilustrativas sobre el grado de desarrollo que exhibían Punta Arenas y su entorno durante la época final de los años dorados de su evolución histórica.

24 Véase en nuestro libro Los alemanes en la Patagonia chilena, ya citado, las ilustraciones de la pág. 82 reproducidas por cortesía del señor Martin Skalweit, propietario de las piezas. 
Pues bien, en esta obra que tuvo mucha difusión se incluyen además seis reproducciones en colores de sus pinturas (óleos, guaches) ${ }^{25}$, con las que podemos dar cuenta de la otra actividad de Foresti, la de ser artista pintor, con la que sería más conocido históricamente. Es posible que tuviera alguna formación académica, pero de ser así no ha podido ser constatada fehacientemente. Su obra pictórica, con todo, no parece haber sido muy abundante y originada principalmente en encargos. De colorido más bien apagado, su temática realista estuvo referida a paisajes naturales y culturales de carácter bucólico. A la vista de las reproducciones de sus cuadros se nos antoja que antes de tomar modelos del natural, Foresti utilizó fotografías como referencia. Sensiblemente no se ha conservado, que se sepa, ninguna de sus obras en original como para juzgar con la debida propiedad y certidumbre acerca de la materia.

Aunque no fue un pintor fecundo, Carlos Foresti sí fue un animador de la cultura en general y en particular del arte que cultivaba. En efecto, formó un grupo con el maestro Enrique Artigas Vendrell, con la escultora Laura Rodig y con aficionados como Luis Swart, que dio vida al ambiente cultural excepcional de fines de los años de 1910 con el que se encontró y al que se incorporó Gabriela Mistral cuando arribó a Punta Arenas. Así como antecedió a la llegada de la futura Premio Nobel de Literatura, proseguiría durante el lustro siguiente a 1920, siempre teniendo como animadores principales a Foresti y Artigas. Carlos Foresti se mantuvo vigente en ésas y otras actividades hasta su fallecimiento ocurrido el 27 de julio de $1932^{26}$.

Contemporánea y copartícipe de las inquietudes artísticas de Foresti fue Zillah Goudie. Originaria de las islas Shetland, en el norte de Escocia, hubo de nacer en época que no hemos podido determinar alrededor de 1880. Criada en un hogar austero y

25 Los cuadros titulados: En los canales Beagle. Monte Fantasma, Oyendo la voz del pastor, Cúter en los canales Beagle, Crepúsculo en San Gregorio, Un alba serena y Noche de luna en los canales Beagle. Además, en la portada de la Revista Menéndez Behety N46 de octubre de 1927, presentado bajo el título de Paisaje de la Estancia y Cabaña de Reproductores San Gregorio" Óleo de C. Foresti.

26 En la lápida de su tumba en el Cementerio Municipal "Sara Braun" de Punta Arenas, está ornada con un bajo relieve conformado por la paleta y el pincel del pintor, como atributo significativo de la que si no fue la principal de sus actividades en Magallanes, sí pudo haber sido la preferida. religioso, el rigor paterno orientó su educación bajo cánones severos que apenas si dejaron tiempo para que, a hurtadillas, pudiera como todas las niñas de su edad soñar con y hacer las cosas que le agradaban y por las que tuvo tempranamente una especial inclinación, entre ellas la observación de la naturaleza y su expresión a través de la pintura en acuarela, habilidad que debió aprender y cultivar en la escuela. La voluntad del padre, además de influir en su formación intelectual, la orientó inclusive en su educación superior a través de la elección de una carrera poco frecuente para una mujer de su época, como fue la de ingeniería. Graduada en una de las universidades más antiguas y tradicionales de Gran Bretaña, con experticia en metales, en agrimensura y en geología, hubo de pensar dónde ejercer la actividad profesional y quizá entonces decidió hacerlo lejos, muy lejos de su suelo natal, para dar rienda suelta, imaginamos, a tanto afán contenido por la rigidez de su educación doméstica. Como tantos otros escoceses emigró a Sudamérica, a la Patagonia, en 1907, enterada sin duda como pudo estar sobre la importante presencia de sus paisanos y de otros británicos en el quehacer económico del remoto territorio meridional. Allí unos fungían como estancieros criadores, otros como administradores, técnicos o capataces de establecimientos rurales y unos terceros, en fin, como simples pero eficientes pastores de ovejas.

Esa presencia hubo de permitirle a Zillah Goudie conocer la geografía magallánica en toda su amplitud, aun hasta los lugares más extremos y poco accesibles como eran entonces la isla Navarino y las más lejanas del cabo de Hornos, y disfrutar a gusto con sus atractivos naturales. En tantos viajes que emprendió pudo recoger pictóricamente sus impresiones, a lo menos en sus rasgos fundamentales, que luego podía retocar y terminar en su residencia puntarenense, complementando así la otra actividad que había elegido en su vida habitual ${ }^{27}$. Recogió paisajes y panoramas de la variopinta naturaleza austral, de los establecimientos ganaderos e industriales, que pintaba en acuarela sobre papel de dibujo y en

27 Su inclinación por la enseñanza y su comprensión sobre cómo hacerlo, su afecto por los niños y la necesidad que advirtió había en el ambiente vecinal de una escuela de habla inglesa, la llevó a abrir su propio establecimiento, que mantuvo y regentó por dos décadas a lo menos, circunstancia que, junto con sus dotes como acuarelista, la hicieron conocida de sus connacionales y otros vecinos de Punta Arenas. 
formatos variados, entre pequeños y medianos, con una modalidad estilística y un colorido distintivo a modo de sello personalísimo.

Roque Esteban Scarpa, quien conoció parte de su obra pictórica muchos años después de que Goudie se fuera de Chile, y que admirado por su calidad artística investigó sobre su vida y procuró entender las motivaciones de su espíritu, ha descrito magistralmente su arte, en forma y conceptos que son irremplazables:

Las acuarelas de Miss Goudie son de una nitidez y diafanidad extraordinarias, generalmente sobre una naturaleza en soledad, de cierta placidez, como sorprendida en un eterno amanecer de aires limpios, todo visto con una distancia y serenidad evidentes. Se advierte su amor por lo que pinta, la complacencia en el matiz, en el detalle, pero unos ojos ajenos al paisaje, lo contemplan con morosidad extasiada, extienden su mirada hasta los planos alejados o evanescentes en el juego de luces $^{28}$.

Sin embargo esta mujer sensible no fue feliz en su existencia. Sus ideas liberales y su manera poco femenina de conducirse que pudieron resultar chocantes para muchos, debieron mezquinarle la simpatía ajena, y así acabó aislándose, cayendo en el vicio de la dipsomanía, empobreciéndose inclusive económicamente. Aunque tuvo la opción de retornar a la patria cuando la Gran Guerra Europea, decidió quedarse y así debió afrontar las circunstancias sobrevinientes a su estado de dejación en que su vocación artística hubo de sufrir las consecuencias del abandono. Ello lleva a conjeturar que su vida artística activa se mantuvo por algo más de una década a contar desde su llegada, tal vez hasta fines de la segunda década del siglo XX. En su estado de necesidad, después de 1930 fue llamada por un pariente anciano para que lo cuidara y entonces, cuando no tenía una alternativa mejor, decidió marcharse de una tierra que había llegado a amar con fuerza, llevando consigo los cuadros que le quedaban y en los que había plasmado con talento aquel afecto. Scarpa afirma que algunos años después, al fallecer aquel pariente quedó desvalida, amén de pobre y vieja, terminando recluida en un asilo para ancianos desvalidos. Allí la estepa, el caballo, las ovejas, los

28 "Magallanes visto por ojos de mujer", en Zillah Goudie. Acuarelas. Sala de Exposiciones Valparaíso, marzo de 1978. canales tranquilos y tormentosos, el saber y el enseñar, se encerraron en una habitación sorda llena de espectros, hasta la piadosa liberación de la muerte ${ }^{29}$.

Su alejamiento y la paulatina desaparición de quienes la habían conocido y tratado condujeron al olvido de su memoria que sólo pudo conservarse, como algo íntimo, por una descendiente británica que había sabido valorar sus acuarelas, la señora Lina Trehern Perkins. Por ella Roque Esteban Scarpa, cuando ejercía la responsabilidad de la Dirección de Bibliotecas, Archivos y Museos, supo de Zillah Goudie y de ella adquirió una colección de veintidós cuadros, como un preciado acervo característico e histórico ${ }^{30}$. Scarpa valoró tanto su descubrimiento que consideró que esa muestra particular de arte pictórico debía ser conocida en el ambiente de la cultura. De esa manera realizó la primera exposición de acuarelas de Zillah Goudie, con la colección adquirida por aquél, en marzo de 1978 en la Sala de Exposiciones Valparaíso, muestra que posteriormente fue repetida en Punta Arenas, en el Museo Regional de Magallanes y siempre con el patrocinio de la Dirección de Bibliotecas, Archivos y Museos. En ambas oportunidades el ilustre literato magallánico manifestó su intención de hacer retornar a su tierra de origen las preciadas acuarelas de Goudie, considerando que tal habrá de suceder en el momento en que le dé importancia debida a la cultura y a su propia imagen más espiritual $y$ permanente 31 .

Enrique Artigas Vendrell (1866-1937), pintor de origen catalán, llegó a Punta Arenas en el curso de los años de 1910 gozando de cierto prestigio por su formación académica sólida y por la fama de algunos de sus trabajos. Eso lo hace atípico entre los pintores que residieron en Magallanes, mayoritariamente autodidactas, como lo es asimismo su obra conocida y documentada.

Natural de Begas, Barcelona, inició su formación en la Escuela Oficial de Bellas Artes de su ciudad natal, que coronó con menciones honoríficas y premios, circunstancia que le permitió acceder

29 Ibid.

30 Hay además una decena de piezas firmadas por la autora en poder de diferentes familias magallánicas, tanto en Punta Arenas como en Santiago.

31 La colección es conservada actualmente por Juan Scarpa, hijo adoptivo y heredero del Premio Nacional de Literatura. 
al curso superior de pintura al natural a cargo de Antonio Caba, retratista afamado (1887). Esta formación había contemplado en simultaneidad estudios teóricos (Perspectiva, Anatomía Artística, Historia de las Bellas Artes y Artes Suntuarias) con otros calificados docentes. Concluida esa etapa, Artigas pasó a ser discípulo, colaborador y amigo de José Luis Pellicer, director artístico de la casa editorial Montaner y Simón, y reputado como uno de los mejores dibujantes españoles de la época, así como fue discípulo del gran paisajista Modesto Urgell. Ansioso por aprender y calificar apropiadamente su formación, la completó finalmente con estudios en el curso superior de dibujo al natural de la Escuela Oficial de Bellas Artes de San Fernando, Madrid, y en el Museo Nacional de Pintura de la misma capital.

Así inició una exitosa carrera pictórica que incluyó los retratos de S. M. doña María Cristina, Reina Regente de España, y de la infanta Isabel de Borbón y de otras personalidades de la nobleza hispana, lo que le cimentó una temprana fama. En 1911 emigró a la República Argentina, estableciéndose en Buenos Aires como retratista, con gran éxito. Su sólida formación artística y sus antecedentes le llevaron a relacionarse de algún modo con el obispo y Vicario Apostólico de Magallanes, monseñor Abrahán Aguilera, quien le encargó la decoración al óleo del ábside y el presbiterio de la Iglesia Matriz y Vicarial de Punta Arenas (actual Catedral), obra decorativa con la que la autoridad eclesiástica quiso adherirse a los festejos del cuarto centenario del descubrimiento del estrecho de Magallanes, en 1920.

El conjunto pictórico estuvo formado por tres grandes frescos: el mayor y principal en la semicúpula del ábside, conformado por el grupo que representa a la Santísima Trinidad coronando a la Santísima Virgen María con el hábito de la Orden de la Merced (en su calidad de copatrona del templo) ${ }^{32}$; el segundo, en la bóveda del presbiterio, zona superior, expresivo del triunfo de la Religión Católica en Magallanes, significado por el esfuerzo y los trabajos de la Congregación Salesiana, con la

32 Este fresco resultó dañado durante el gran incendio de febrero de 1979 que consumió el edificio colindante del antiguo Colegio "San José", por lo que considerado irrecuperable, fue reemplazado posteriormente con un gran mosaico representativo de Cristo Pantocrátor, obra artística del salesiano P. Luis Mebold. representación de la Caridad, figurada en un ángel colosal con las alas abiertas, que porta en su mano derecha la Santa Cruz y en la izquierda la Biblia, y cuyos pies se apoyan en el escudo del Territorio de Magallanes y la tiara pontificia. Más abajo, a izquierda y derecha del ángel, las figuras epónimas de los misioneros monseñor José Fagnano y sor Angela Vallese, rodeados de alumnos, alumnas y niños indígenas, además de los atributos de las ciencias y las artes, y una franja heráldica; y el tercero, en los sectores laterales del presbiterio, con la representación de los Evangelistas, dos a cada lado de la bóveda. Estos conjuntos fueron complementados con una serie de adornos secundarios en las paredes laterales del presbiterio, pilares, arcos, cornisamientos, capitales y plafones ${ }^{33}$.

La así descrita someramente conformó la obra pictórica cimera de Enrique Artigas en Magallanes, admirada y alabada desde el momento mismo de su inauguración, por su calidad en la ejecución y el apropiado colorido, así como por la fuerza expresiva y simbólica de las figuras, y que se conserva hasta el presente como una muestra cabal del grado de desarrollo artístico alcanzado por Magallanes al concluir la época dorada de su evolución.

Pero, además de ella y durante los años que inmediatamente siguieron, el pintor trabajó en la ejecución de una serie de grandes retratos de personajes religiosos (monseñor José Fagnano, los obispos Abrahán Aguilera y Arturo Jara Márquez, su sucesor, y el Papa Benedicto XV) e históricos y en imágenes de santos, óleos que en su mayoría se conservan en los salones de la residencia episcopal en Punta Arenas, del mismo modo como en obras alegóricas pintadas para ornato del Colegio "San José" y que se perdieron durante el siniestro al que se ha hecho mención. Menos conocidos son algunos escasos cuadros con motivos exóticos que fueron el fruto de la fantasía del pintor, hoy en manos privadas.

Artigas Vendrell intervino asimismo, como se ha mencionado antes, conjuntamente con Carlos Foresti, en la difusión del arte pictórico a través de la organización de exposiciones para conocimiento y disfrute de la comunidad y, además creó y dirigió una suerte de academia o taller de formación de

33 Estos frescos ornamentales laterales fueron cubiertos en época reciente durante las obras de refacción de la Iglesia Catedral. 
aficionados. De talante tranquilo y ajeno a la figuración, amén de ser de vida austera, con los años se fue retirando y recluyendo a su círculo familiar. La última actividad que hemos podido registrar para este insigne maestro de la pintura realista, fue su participación en el jurado que resolvió el concurso organizado sobre la especialidad durante la celebración de los Juegos Florales de Punta Arenas en 1936. Tiempo después se alejó de Magallanes para radicarse en Santiago, ciudad en la que falleció el 20 de agosto de 1937.

Para concluir el registro de los pintores residentes en Magallanes, cabe la mención de tres singulares autodidactas: Johanna Roehrs, Marcelino Mulatti y Felipe Cimadevilla.

Johanna Roehrs Bardt (1903-1984), nació en Porvenir, Tierra del Fuego, en el seno de una familia de inmigrantes alemanes formada por Guillermo Roehrs y Emilia Bardt, que se incrementó con otros nueve hijos. La actividad del padre, ligada a la ganadería ovina, llevó a la familia desde el empleo original en la estancia "Gente Grande" hasta la estancia "Glencross", en el distrito del valle medio del río Gallegos, donde aquél asumió la responsabilidad de administrador, cargo que desempeñó por más de tres décadas. Allí transcurrieron los años más plenos y felices de la adolescencia y la juventud de los hermanos Roehrs.

En efecto, además de la instrucción y educación formales impartidos por maestros contratados para el efecto, supieron aprender de la naturaleza patagónica, cuyos secretos descubrieron paulatinamente, llegando a ser todos ellos, cual más cual menos, admirables observadores de la vida silvestre, de las expresiones inertes de la tierra y de los rastros de la humanidad pretérita, y así alcanzaron un asombroso conocimiento naturalista como pocos han podido conseguirlo en circunstancias parecidas.

Johanna, Hanni familiarmente, dueña de una particular sensibilidad y dotada de capacidad para el dibujo, orientó su personal sentido de observación hacia las distintas manifestaciones de la vida natural, y las recogió quieta y amorosamente en sencillos bocetos y en trabajos acabados, éstos de rara fidelidad expresiva. En esta tarea estuvo especialmente activa entre los años de 1920 y los de 1960.

Al contemplar estas obras simples y sin pretensión, surge la duda de estar o ante una dibujante impresionada por los elementos de su entorno, o mejor, ante una observadora singular que con acucia digna de científicos ha recogido las características de las distintas especies que concitaron su interés, al punto que varios de sus trabajos recuerdan cercanamente las magníficas obras de los antiguos naturalistas viajeros. De tal modo, cultivando su facilidad perceptiva y su habilidad reproductiva de raro verismo, Hanni llegó a convertirse en una autodidacta artista del lápiz y del pincel.

Aves, plantas y flores fueron sus motivos predilectos. Así, retrató a la loica y la torcaza, a cernícalos y aguiluchos, al diucón, al chincol y al tijeral y varias otras de nuestras más hermosas y llamativas especies de la avifauna patagónica. Pero las plantas y flores parecieron concitar un interés especial y en este grupo de motivos vemos a las orquídeas, escalonias, prímulas y calceolarias, al calafate, la zarzaparrilla, la paramela y la acaena, entre otras especies vegetales. Aquí es donde al pintar vivisectó flores y plantas para un mejor estudio de sus formas características y agregó anotaciones para su apropiada identificación. Por fin, su conjunto de hongos silvestres es espléndido por su fidelidad, tanto que el mismo pudo ser utilizado hace algunos años en una comunicación científica de la Universidad de Magallanes. Es entonces, al enfrentarnos con estos dibujos, cuando nos preguntamos si la dibujante es una artista o una auténtica naturalista de circunstancias. En verdad, si lo uno y lo otro, que hay de ambos rasgos, en la inspiración y en la magistral ejecución de gran realismo es evidente el sentimiento de cariño profundo por el terruño austral. Los paisajes, aunque minoritarios en su tarea creativa, también le interesaron y en especial aquellos propios de la estepa, ambiente en el que Hanni vivió desde la niñez hasta la edad madura y del que hubo de recibir un fuerte influjo telúrico. Con su maestría consiguió hacer de los mismos, donde la monotonía en las formas brinda escasa motivación al artista, paisajes singulares y atractivos gracias al manejo de los cielos que con su dinámica variabilidad en las formas de las nubes permiten compensar aquella limitación y brindar al fin una visión panorámica que resulta grata para el observador.

Fue el sortilegio de la naturaleza en una mujer de sensibilidad exquisita y que acabó plasmado en dibujos y pinturas que su autora guardó como tesoros íntimos, al punto que sólo pudieron ser conocidos 
públicamente varios años después de su fallecimiento. En efecto, nuestra amistad con Hans Roehrs, hermano menor de Hanni, nos permitió acceder a ese acervo cuidadosamente conservado por él y por su hermana Tila. En total, dos centenares de trabajos hechos sobre papel de dibujo y tarjetones principalmente, a lápiz (negro y colores), acuarela, plumilla y tinta china, y óleo, durante un período que se extendió desde los comienzos de los años de 1920 hasta los de 1960, aunque con una actividad más frecuente entre los 20 y los 40 . La forma de ejecutar era sencilla: cada vez que salía al campo, portaba consigo papel y lápices y sentada junto o en proximidad del motivo de su interés hacía un bosquejo o derechamente un dibujo acabado, que, de cualquier manera, retocaba al regresar al hogar ${ }^{34}$. No fue la única en hacerlo entre los hermanos pues también sus hermanas Grete, Tila y Ella mostraron inclinación por el arte pictórico y dejaron dibujos y pinturas igualmente logradas.

La calidad que advertimos en la obra pictórica de Hanni Roehrs nos llevó a organizar, con el patrocinio de la Universidad de Magallanes, una exposición con una selección de sus trabajos, y que se realizó en el Museo Regional de Magallanes durante junio de 1995 bajo el título de Hanni Roehrs: amor por la tierra.

Marcelino Mulatti Gorza (1886-1978), natural de la ciudad de Viedma, Argentina, arribó junto con sus padres inmigrantes tal vez hacia fines del siglo XIX o en los comienzos del XX. Aficionado a la pintura desde joven comenzó a pintar con motivos tomados de la naturaleza o generados por su fantasía creadora. Pareció haber tenido una predilección particular por los árboles, pues la presencia de los mismos es recurrente en sus obras. Su actividad artística la desarrolló por el solo placer de pintar, aunque también pudo recibir algún encargo. Su producción, al parecer toda ejecutada en óleo sobre madera terciada o prensada, se ha conservado en general entre amigos y parientes a quienes Mulatti obsequió en vida.

Felipe Cimadevilla Fernández (1910-1943), vástago de una familia de inmigrantes asturianos, mostró tempranamente aptitud y talento para el dibujo y la pintura. Afectado por una enfermedad congénita

34 La temática de plantas diversas y flores comprende la mitad de las piezas del acervo, seguida en número decreciente por las correspondientes a aves, paisajes y varios (animales domésticos, insectos, peces, huevos de aves silvestres). de tipo muscular que le impedía desplazarse por sí mismo, encontró en su vocación artística un motivo que tanto le satisfizo espiritualmente, como llenó de actividad su existencia, lo que le permitió sobrellevar su severa limitación física. Advertida su inclinación por el arte pictórico, su padre le brindó la posibilidad de cultivarla y perfeccionarla tomando clases con el maestro Enrique Artigas, quien valoró sus cualidades e hizo de él un discípulo aventajado.

Cimadevilla comenzó a pintar en su adolescencia, a los 15 años, y se mantuvo particularmente activo hasta 1936, disminuyendo su ritmo de trabajo en los años que siguieron como consecuencia del mal que padecía y que le condujo a la muerte a los 33 años, en 1943. Pintor universalista en cuanto a su motivación forzado como estuvo por su limitación, trabajaba sobre modelos impresos (figuras, escenas, paisajes), aunque también con composiciones preparadas del tipo de naturaleza muerta. Lo hizo utilizando óleo sobre tela, pero también trabajó con lápiz de carboncillo, especialidad que desarrolló en forma magistral a juzgar por algunos de sus trabajos en papel de dibujo. Laborioso, produjo alrededor de setenta obras (óleos) de todo tamaño, incluyendo algunos cuadros grandes, la mayoría de los cuales se conserva en poder de la familia CimadevillaRodríguez como un preciado legado artístico. De tantos cuadros son especialmente dignos de mención aquellos que conforman la serie de las estaciones de la naturaleza, Primavera, Verano, Otoño e Invierno, La niña de la paloma, El hombre de la pipa, Descendimiento, Rosas, El desierto, en los que se aprecian su notable maestría, su acierto en el empleo de la luz y los colores, y la naturalidad expresiva. En los Juegos Florales de Punta Arenas, en 1936, fue premiado con medalla de oro en la categoría "óleo libre", por un jurado donde estaba su antiguo maestro Enrique Artigas. Conservada amorosamente y exhibida exclusivamente en el ámbito familiar, la obra pictórica de Felipe Cimadevilla (h), como acostumbraba a firmarse, fue virtualmente desconocida por sus coterráneos, los que tardíamente pudieron enterarse y disfrutar con ella con ocasión de la muestra pictórica organizada por la Sociedad Española de Punta Arenas, en sus salones, en octubre de $1987^{35}$.

35 La exhibición comprendió 33 óleos. Parte de esta obra había sido exhibida antes en el Museo Vicuña Mackenna de Santiago. 
Los artistas que se han mencionado completan, algo arbitrariamente, el registro de los pintores residentes para los efectos de este trabajo, pero cabe agregar que ellos no fueron los únicos, tal vez los más conocidos en su momento, y que también hubo otros cultores de relevancia menor tales como Hebe Contardi, Leonor Hrdalo de Andrade y Estrella Palma de Mattioni, quien obtuvo una medalla de oro en los Juegos Florales de 1936, que iniciaron y desarrollaron alguna actividad pictórica hacia la época final del período que nos ocupa (década de 1940).

Por último, lo que prueba la preocupación de los artistas entonces vigentes, como la aceptación que brindaba el ambiente puntarenense de la época a las muestras culturales, debe hacerse mención de la realización del Primer Salón de Artes Plásticas (1939), en el que se presentaron 250 obras de pintores chilenos como Juan Francisco González, Luis Strozzi y Pablo Burchard, entre otros. El salón, que fue todo un suceso con el que en cierto modo culminó culturalmente una época, fue presentado por la escultora Laura Rodig, antigua compañera de Gabriela Mistral en jornadas docentes del Liceo de Niñas, y dio motivo, además, a otras actividades extensivas plásticas, literarias y musicales.

\section{CONCLUSIÓN}

Lo expuesto en el artículo, se reitera, no pasa de ser un conjunto de noticias históricas que permite conocer sobre el origen y la evolución de la pintura realista en Magallanes a lo largo de un siglo contado desde la llegada y trabajos en 1834 del primer pintor propiamente moderno, Conrad Martens, cuya consideración más acabada y profunda es materia que deberá ser abordada alguna vez por un especialista en historia del arte. Tanto en el caso de los pintores viajeros, como y especialmente en el de los residentes, las correspondientes obras no son comparables entre sí, ni ha sido nuestra intención hacerlo, y la mención de las mismas debe ser recibida como la correspondiente a las manifestaciones de un afán creativo y realista para representar el atractivo, interesante y sugerente ambiente geográfico y humano del meridión de América.

\section{AGRADECIMIENTOS}

Dejamos constancia de nuestro agradecimiento para cuantos nos brindaron noticias diversas sobre la materia o permitieron conocer las obras pictóricas por ellos conservadas, especialmente a monseñor Bernardo Bastres, obispo de Punta Arenas, al señor Hans Roehrs y señora, a la señora Aracelia Rodríguez vda. de Cimadevilla, al señor Juan Matassi y al Museo Regional de Magallanes. De manera particular dejamos constancia de nuestro reconocimiento al profesor señor Enrique Solanich por la lectura crítica del artículo y por sus atinadas sugerencias que han contribuido a enriquecerlo; y para con el señor Gabriel Bahamonde M., por su colaboración en la obtención de información por Internet y en la preparación del apéndice iconográfico.

\section{FUENTES DE CONSULTA}

a) Libros y documentos impresos

CASAMIQUELA, RODOLFO M., OSVALDO MONDELO, ENRIQUE PEREA y MATEO MARTINIC BEROS. 1991. Del mito a la realidad. Evolución iconográfica del pueblo tehuelche meridional. Fundación Ameghino, Viedma.

CATLIN, GEORGE. 1979. Episodes from Life Among the Indians and Last Rambles. University of Oklahoma Press, Norman.

CUNNINGHAM, ROBERT O. 1871. Notes on the Natural History of the Strait of Magellan. Edimburgh.

DUMONT, D'URVILLE, JULES CESAR. 1846. Voyage au Pole Sud et dans L'Océanie. Atlas Pittoresque. Gide et. Editeurs. Cie. Paris.

DUVIOLS, JEAN PAUL. 1985. L'Amerique Espagnole vue et revée. Les livres de voyages de Christophe Colomb a Bougainville. Promodis. Paris.

FORESTI, CARLOS. 1920. Álbum del Territorio de Magallanes. Buenos Aires.

HURST, ALEX A. 1988. Thomas Somerscales Marine Artist. His life and work. Teredo Books. Brighton, Sussex.

KENT, ROCKWELL. 1999 (1924). Voyaging Southward from the Straits of Magellan. (segunda edición). Wesleyan University Press. Hanover N. H.

KEYNES, R. D. (editor). 1979. The Beagle Record. Selections from the original pictorial records and griten accounts of the voyage of H. M. S. Beagle. Cambridge University Press. Cambridge-London-New York-Melbourne. 
MARTINIC B. MATEO. 1976. Algunos dibujos inéditos de Rugendas sobre indígenas patagones y fueguinos. Anales del Instituto de la Patagonia, VII:59-62.

MARTINIC B. MATEO. 1999. Cartografía Magallánica 15231945. Ediciones de la Universidad de Magallanes. Punta Arenas.

MARTINIC B. MATEO. 2005. Recorriendo Magallanes antiguo con Theodor Ohlsen (segunda edición). Methanex. Punta Arenas.

MARTINIC B. MATEO. 2005. Los alemanes en la Patagonia chilena. Hans Storandt editor. Santiago.

MARTINIC B. MATEO. 2006 (1992). Historia de la Región Magallánica, 4 tomos. Ediciones de la Universidad de Magallanes. Punta Arenas.

MARTINIC B. MATEO Y DAVID M. MOORE. 1982. Las exploraciones inglesas en el estrecho de Magallanes 1670-1671. El mapa manuscrito de John Narborough. Anales del Instituto de la Patagonia. 13:7-20.

MUSEO HISTÓRICO NACIONAL. 1988. Primera Visión de Chile. Dibujos de la Colección Germán Vergara Donoso. Con el auspicio de Esso Chile Petrolera S. A. Santiago.

R.A. 1920. Las decoraciones de la Iglesia Matriz y Vicarial. Punta Arenas.
ROJAS MIX, M. A. 1970. La imagen artística de Chile. Editorial Universitaria, Santiago.

SAGREDO BAEZA, RAFAEL Y JOSÉ IGNACIO GONZÁLEZ LEIVA. 2004. La Expedición Malaspina en la frontera austral del imperio español. Centro de Investigaciones Diego Barros Arana-Editorial Universitaria. Santiago.

SCARPA, ROQUE ESTEBAN. 1978. "Magallanes visto por ojos de mujer". En Zillah Goudie. Acuarelas. Catálogo Sala de Exposiciones Valparaíso. Valparaíso.

SOLANICH SOTOMAYOR, ENRIQUE. 1987. Dibujo y Grabado en Chile. Departamento de Extensión Cultural del Ministerio de Educación. Serie Patrimonio Cultural Chileno. Historia del Arte. Colección Historia del Arte Chileno. Santiago.

SCHWEMBER FERNÁNDEZ, ENRIQUE. 2006. Significación de la obra de Pedro Luna. Tesis para optar al grado de Magíster en Artes con mención en Teoría e Historia del Arte. Universidad de Chile, Santiago.

b) Pinacotecas y colecciones

Obispado de Punta Arenas. Residencia Episcopal; Museo Regional de Magallanes; colecciones familias Cimadevilla Rodríguez, Fernández-Dübrock, RoehrsGonzález y Matassi-Alonso. 


\section{APÉNDICE ICONOGRÁFICO}

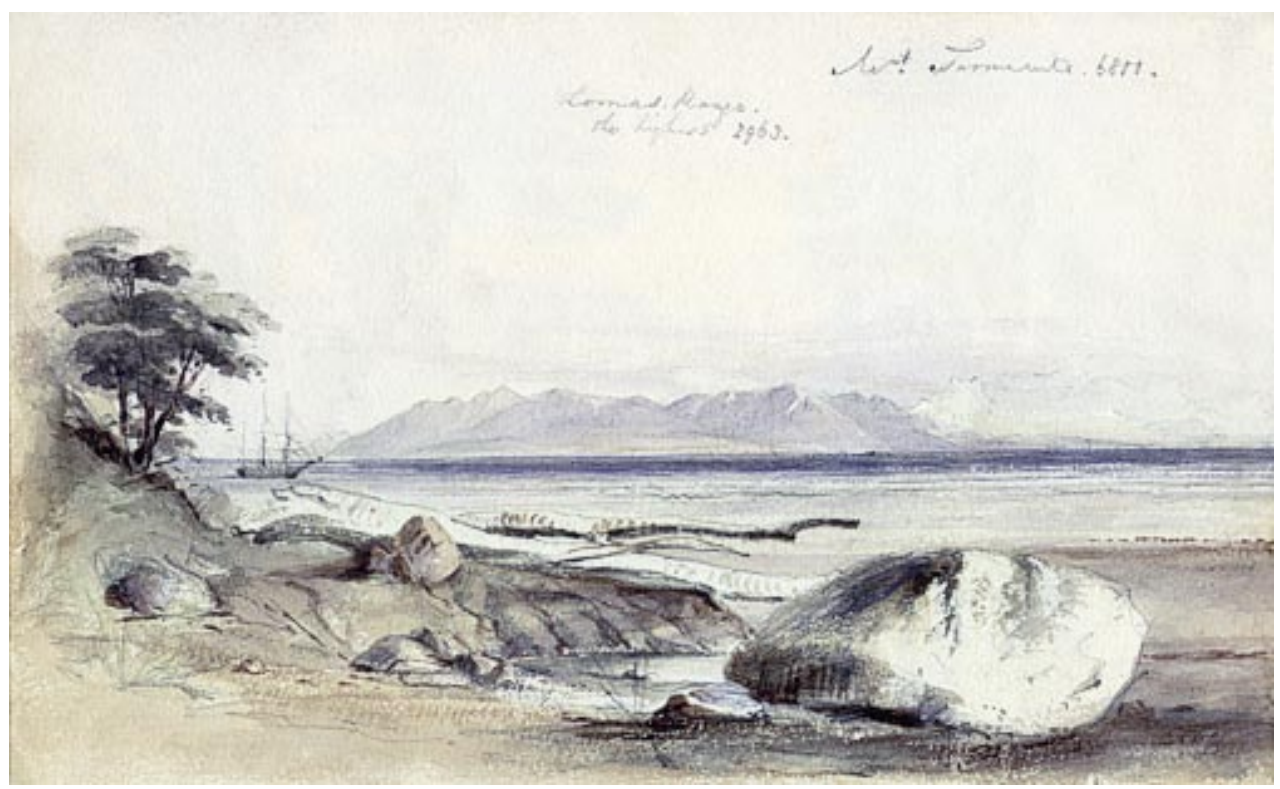

1. Conrad Martens Mount Sarmiento and the Lomas Range (1834).

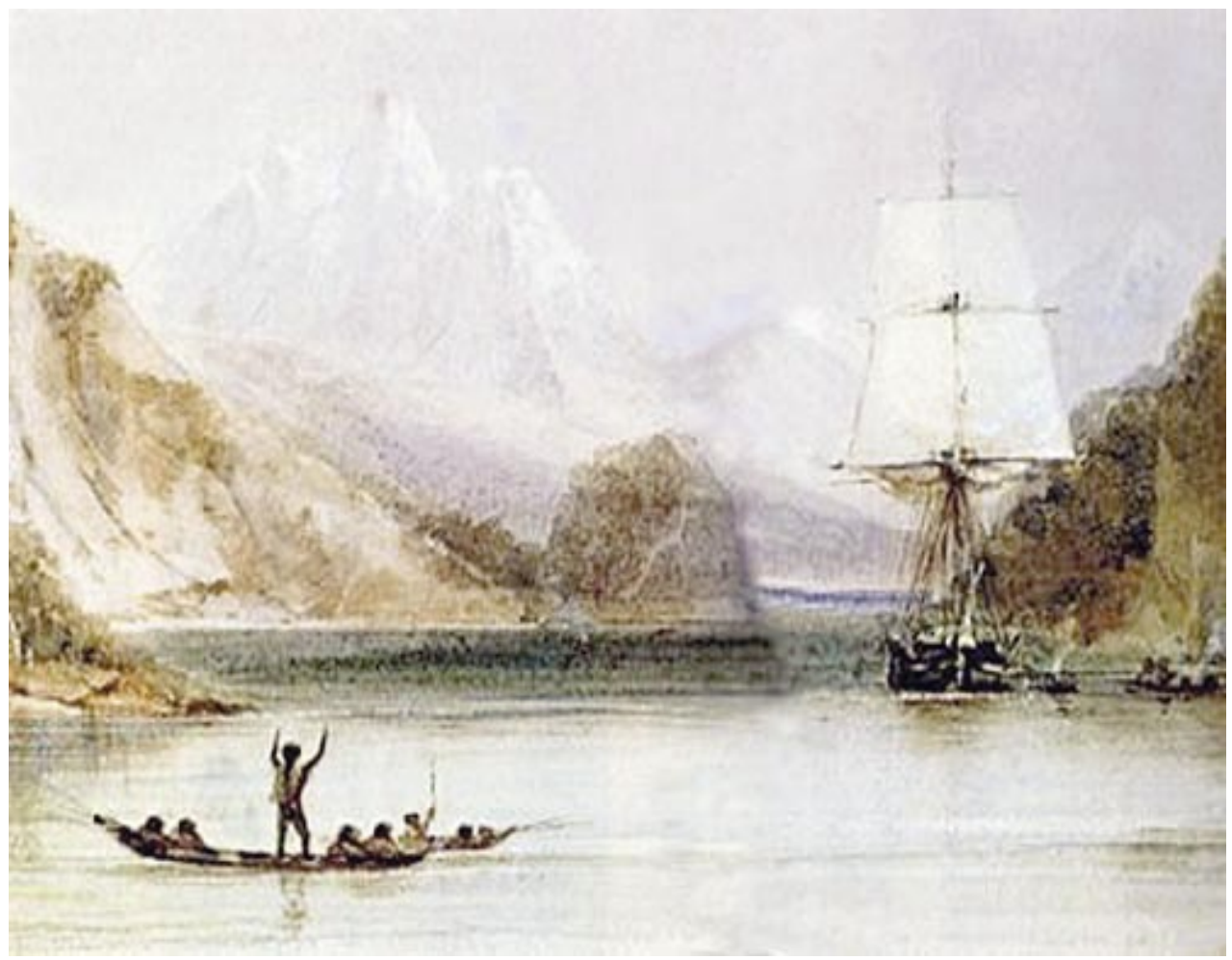

2. Conrad Martens The Beagle in the Murray Narrows (1834). 


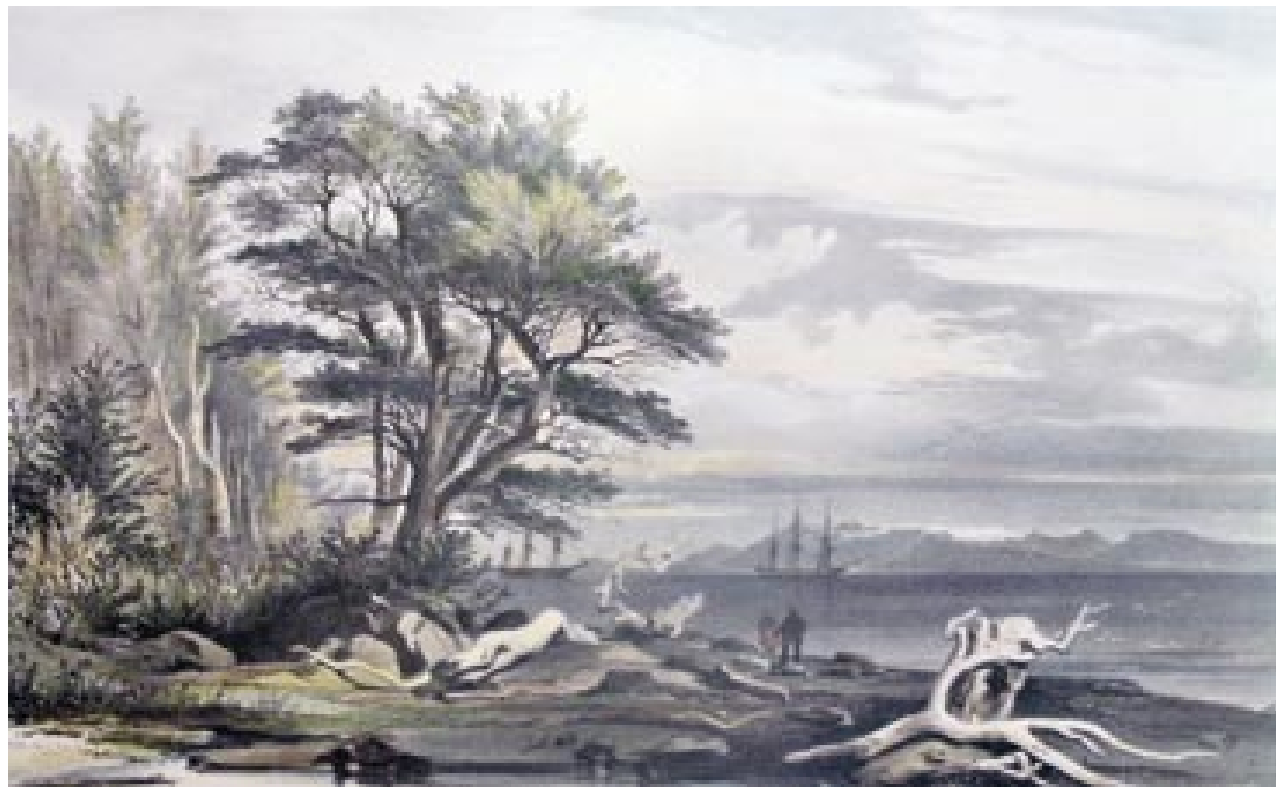

3. Ernest Goupil Port Famine (1837). Grabado de Emile Lasalle.

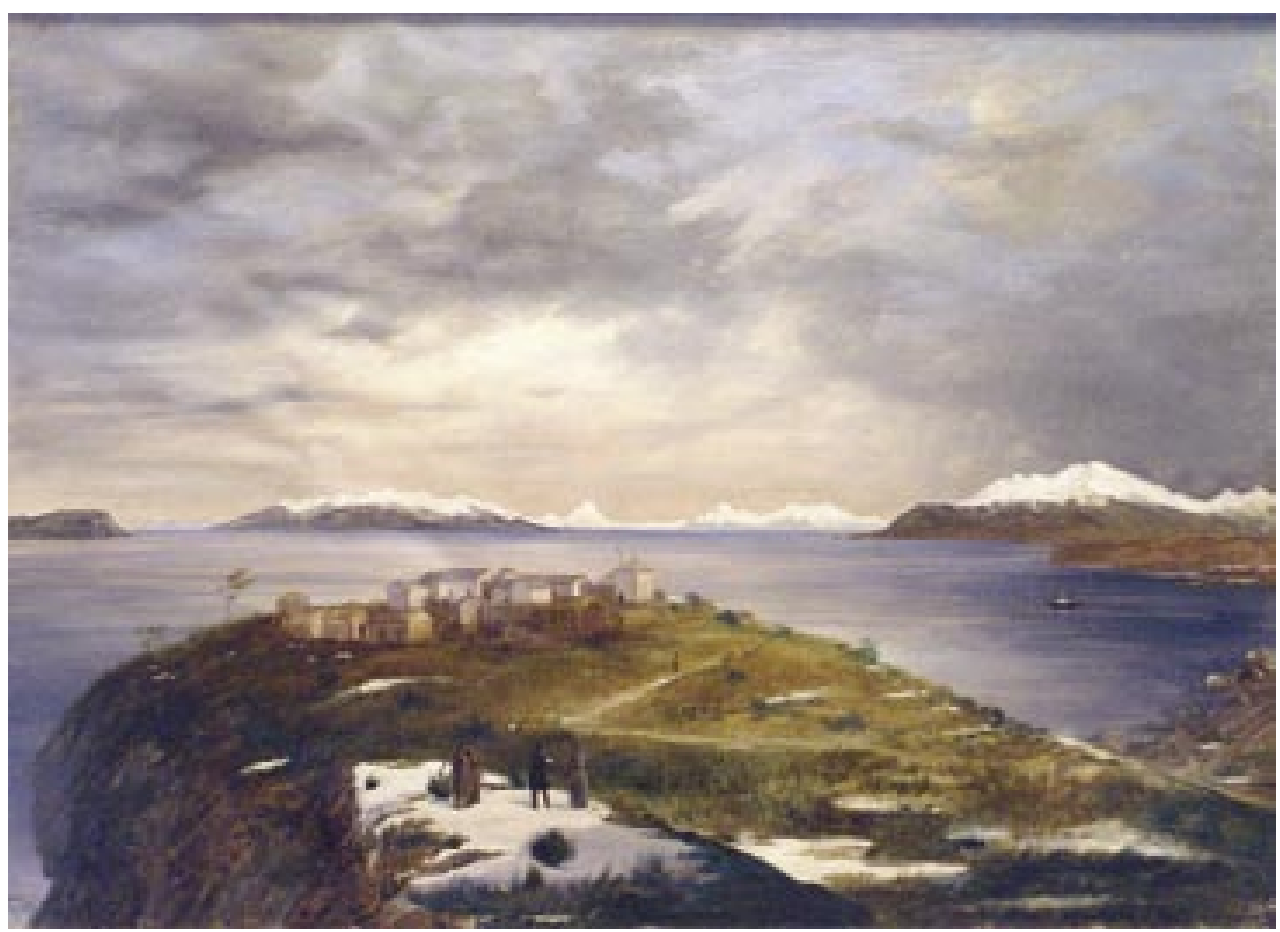

4. Alejandro Cicarelli Fuerte Bulnes (1847). 


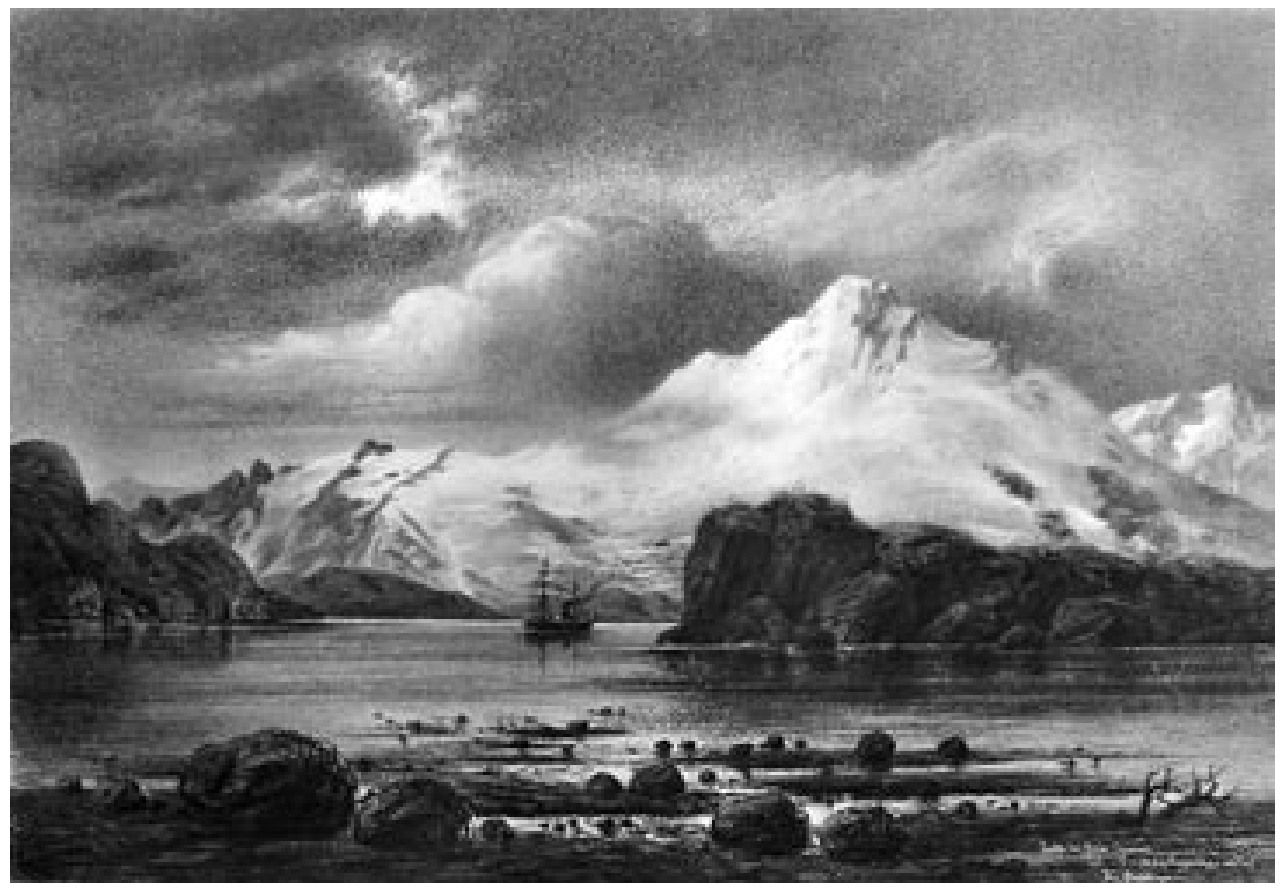

5. Theodor Ohlsen Navegando por Angostura Guía (época indeterminada).

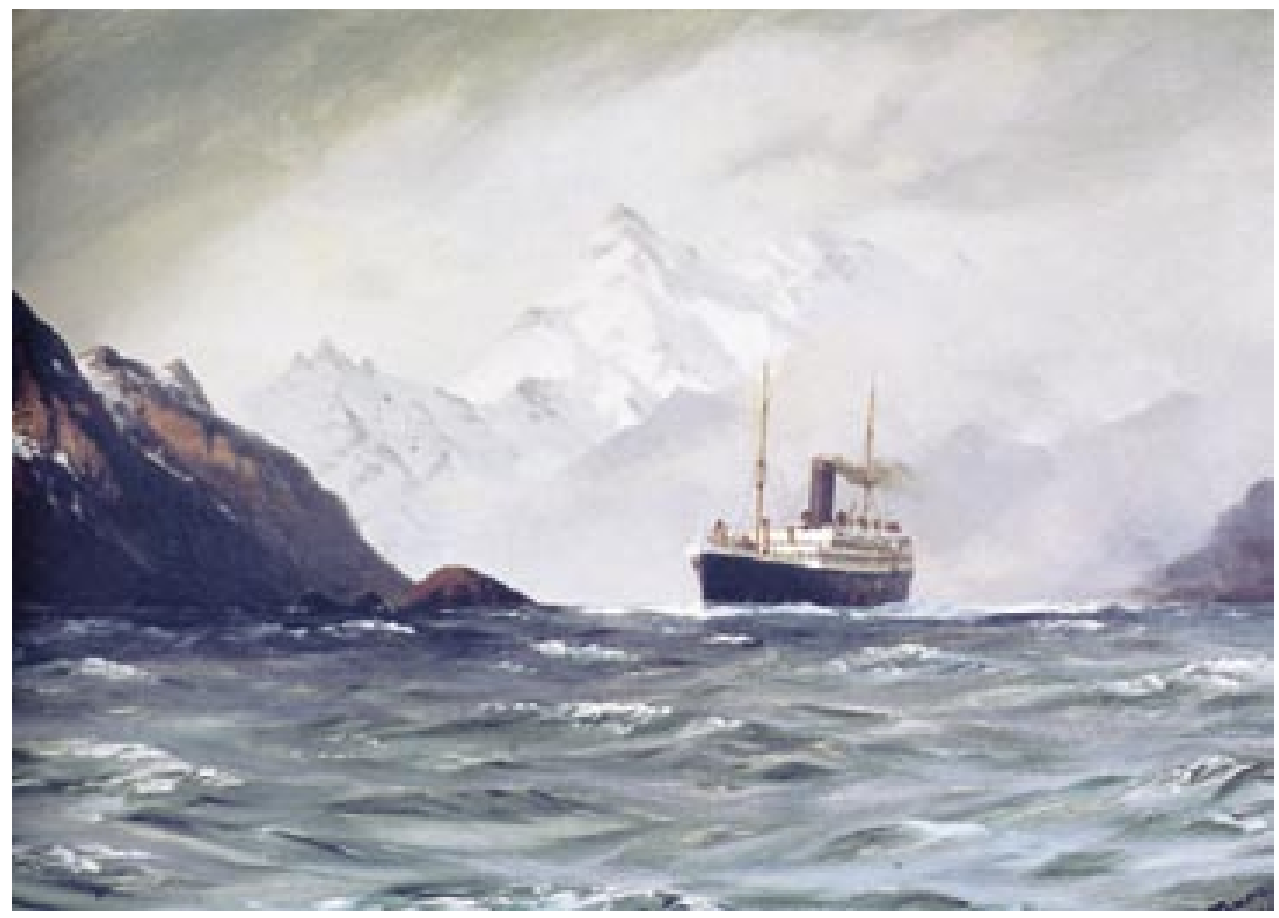

6. Thomas Somerscales A Pacific Steam Navigation Co. vessel in the Straits of Magellan (1910). 


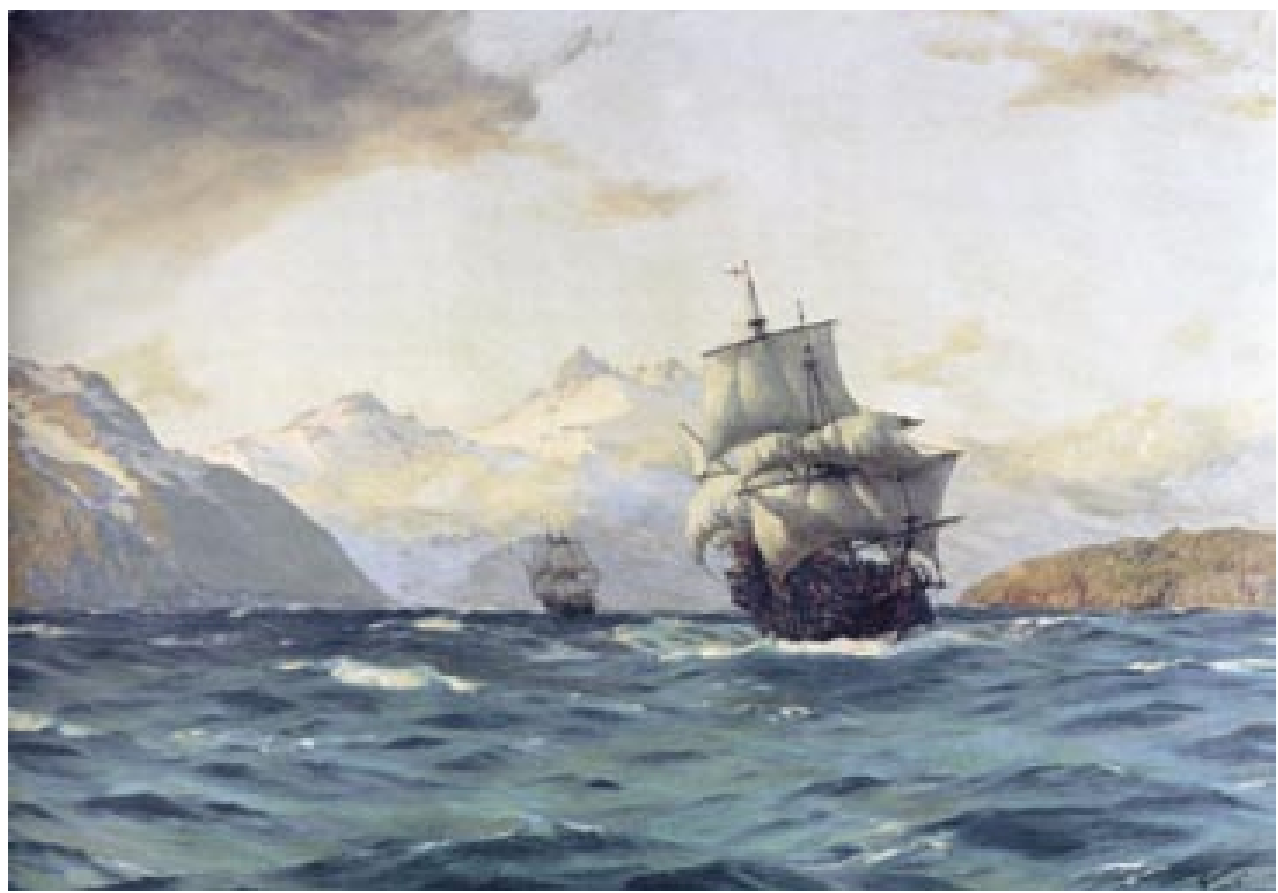

7. Thomas Somerscales Francis Drake's passage through the Straits of Magellan (1914).

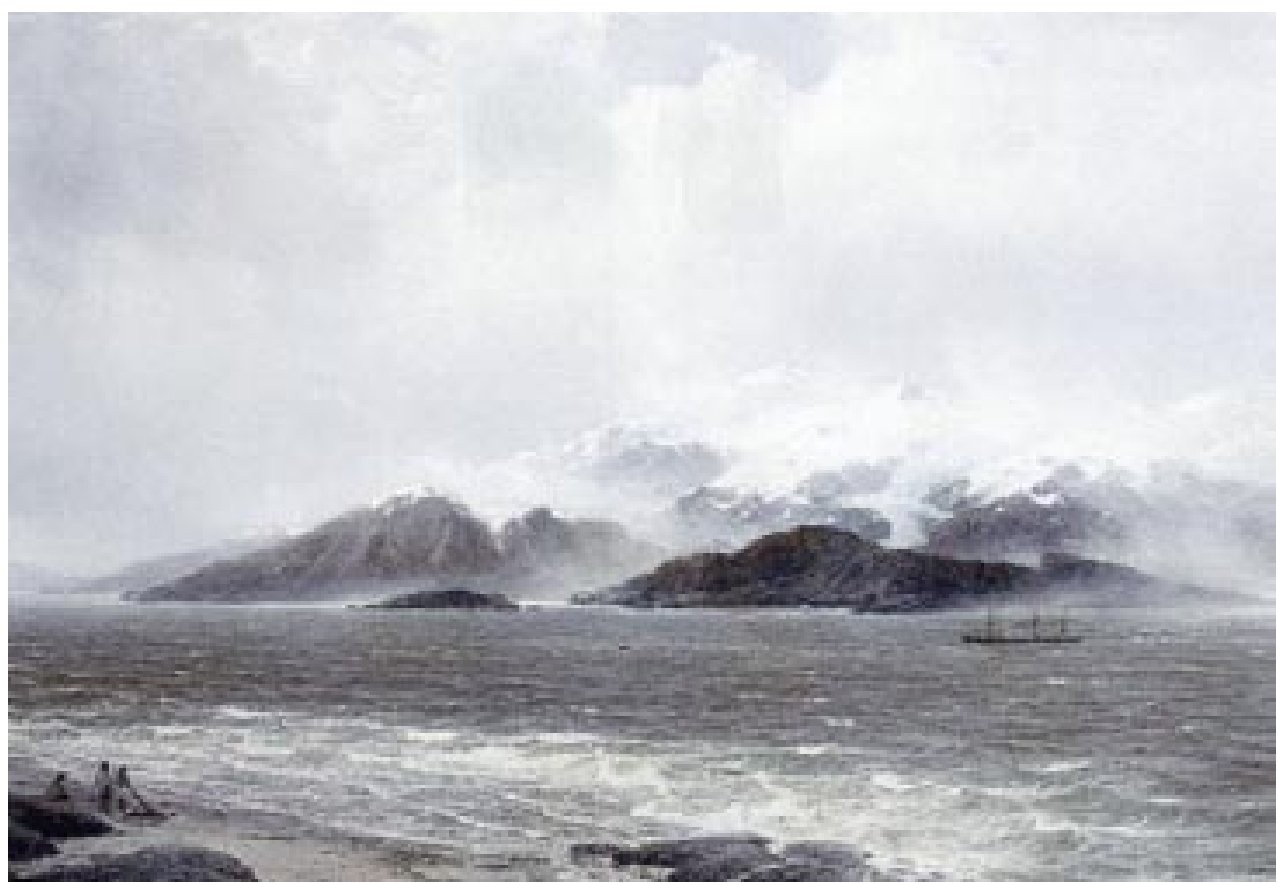

8. Carl W. Schnars - Alquist Vapor navegando por el estrecho de Magallanes (época indeterminada). 


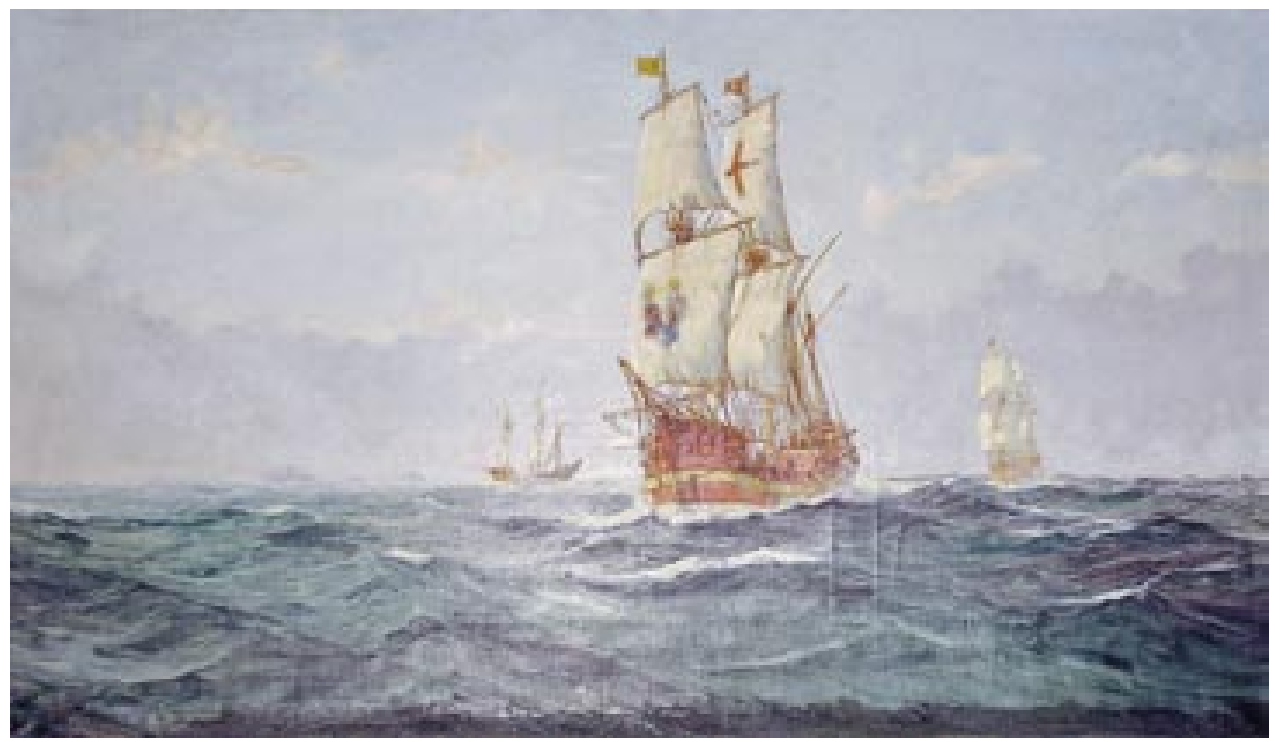

9. Álvaro Casanova Zenteno Descubrimiento del estrecho de Magallanes (¿1920?).

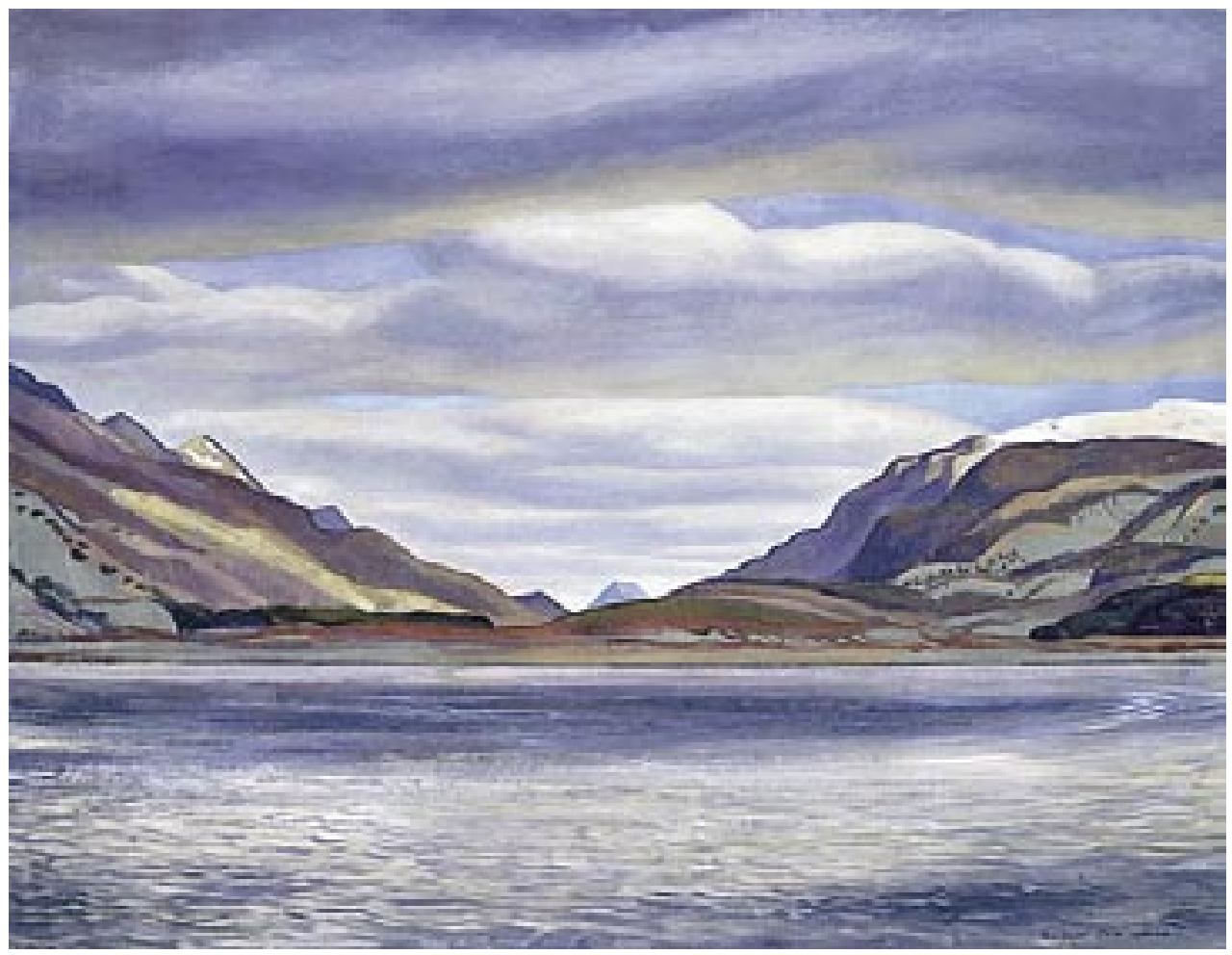

10. Rockwell Kent Valle del río Azopardo hacia el lago Fagnano (1923). 


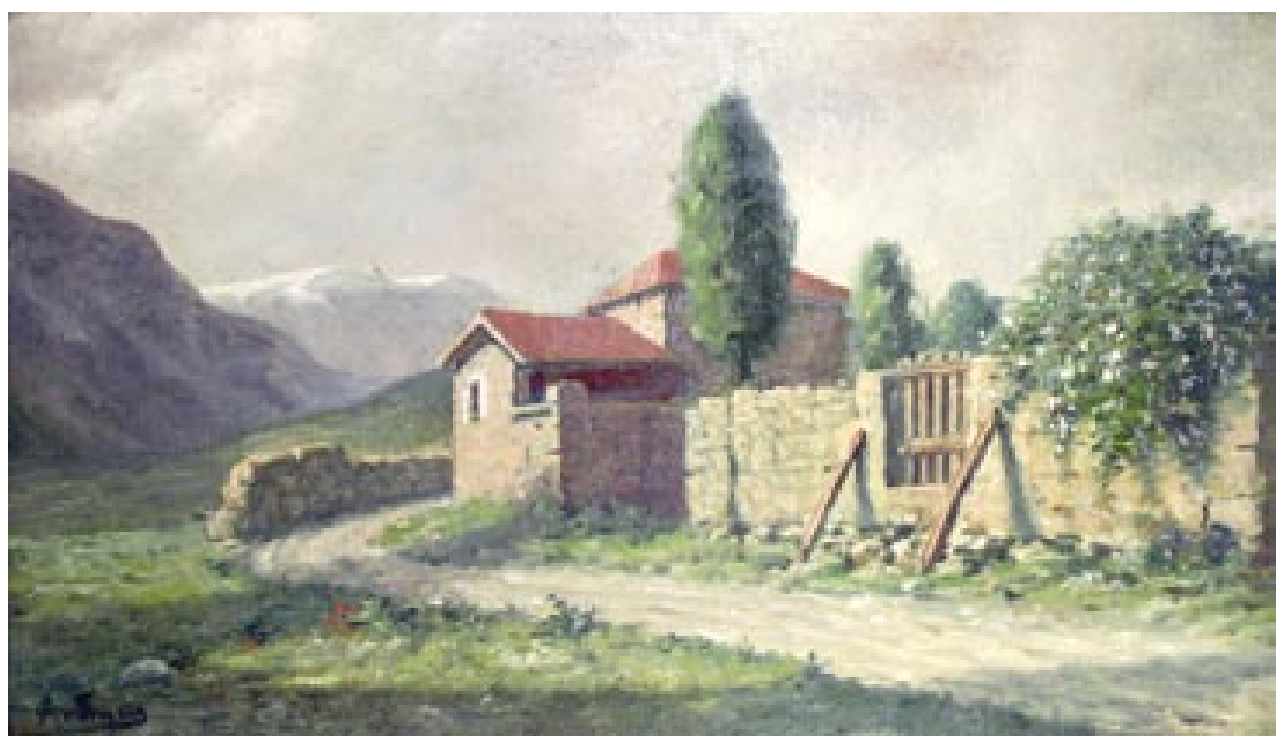

11. Enrique Artigas Vendrell Paisaje (época indeterminada).

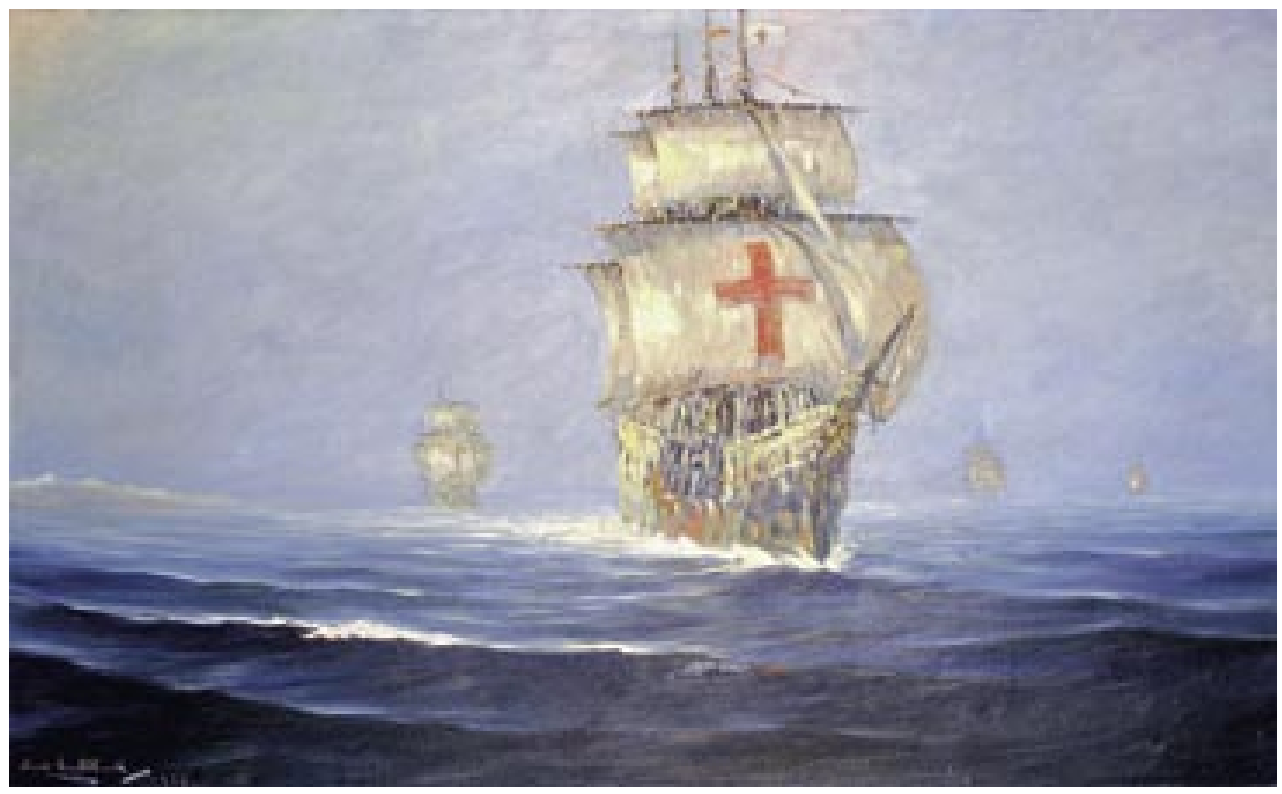

12. Stephen Koek - Koek Descubrimiento del estrecho de Magallanes (1933). 


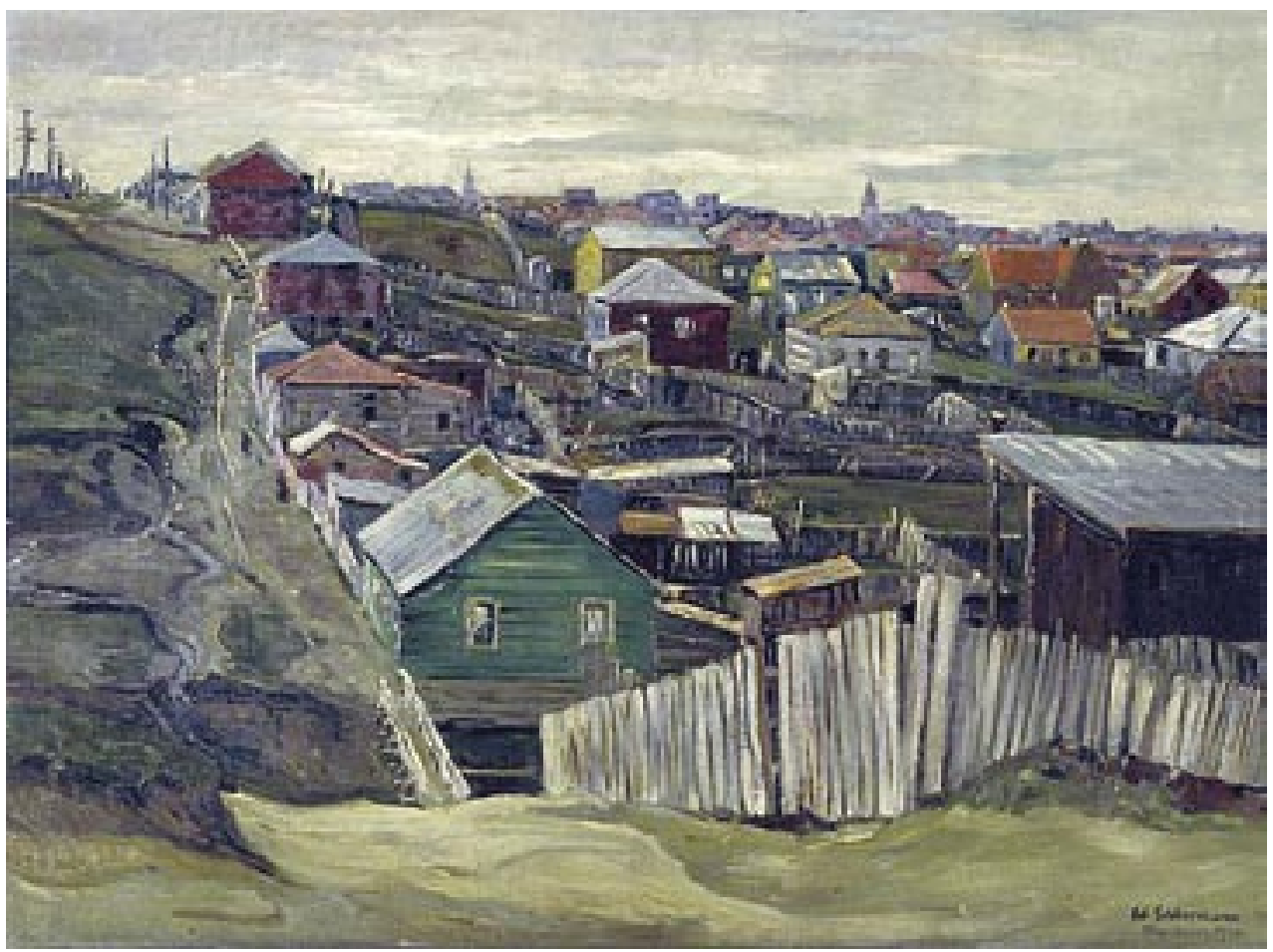

13. Eduard Schloemann Barrio de Punta Arenas (ca. 1930-32).

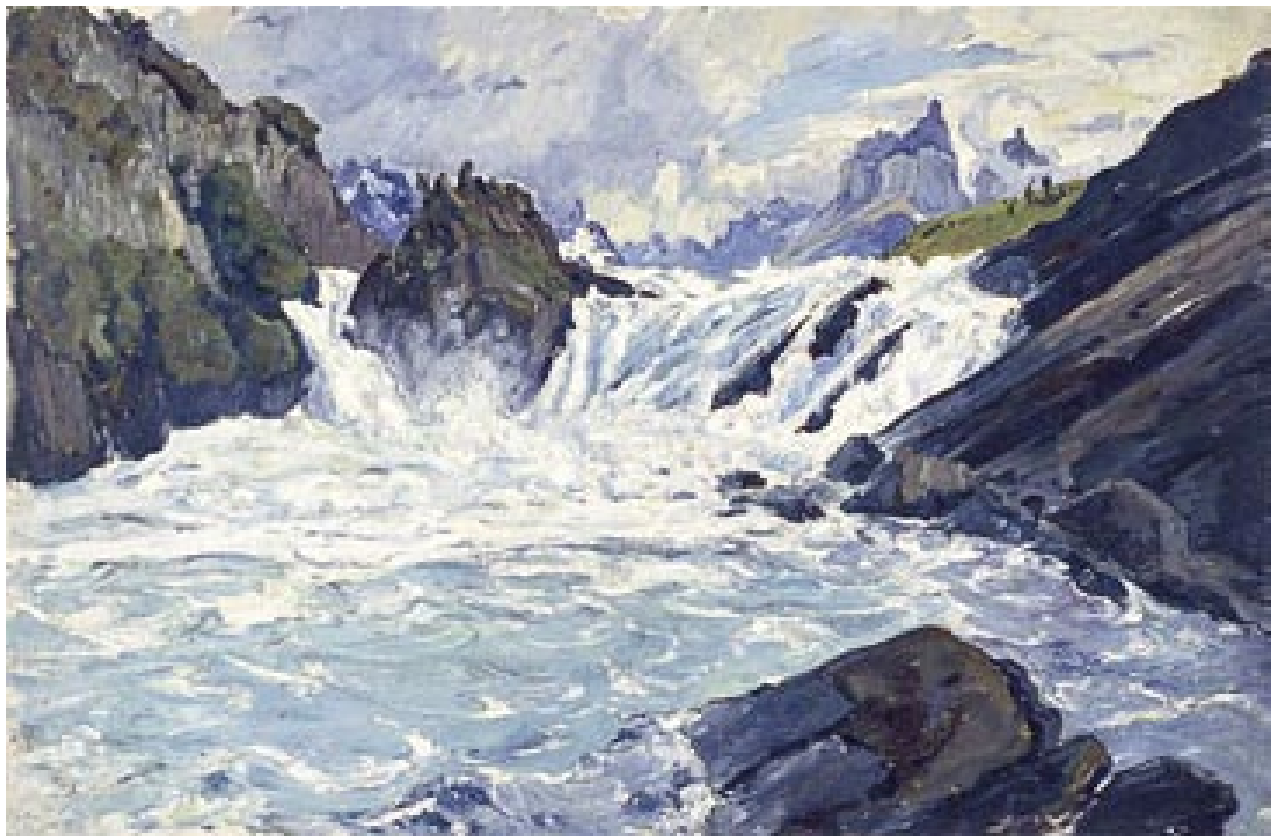

14. Eduard Schloemann Paisaje del Paine (ca. 1930-32). 


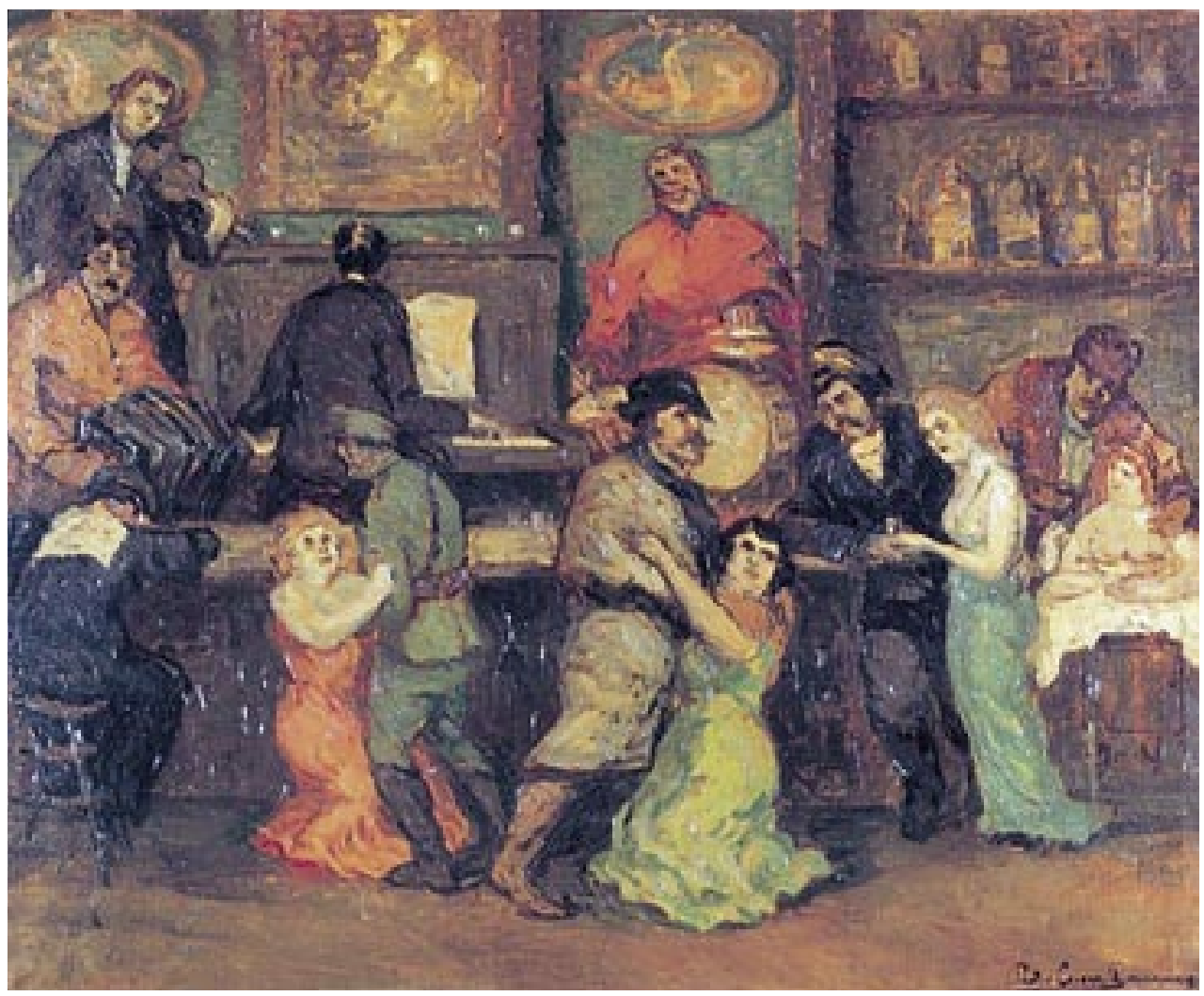

15. Pedro Luna El baile de las Enanas (1936).

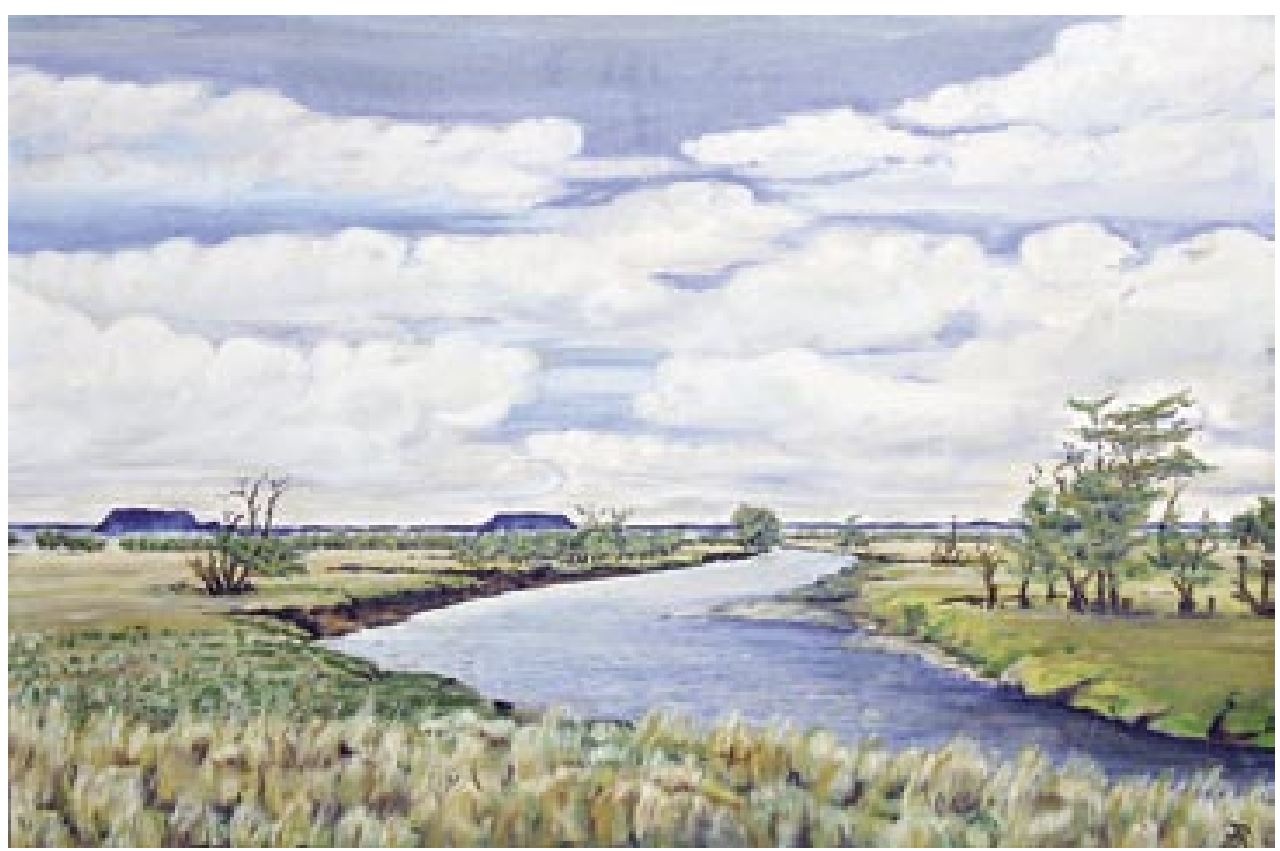

16. Johanna Roehrs Paisaje en el valle del río Penitente (época indeterminada). 